Journal of Fish Diseases

May 2017, Volume 40, Issue 5, Pages 717-742

http://dx.doi.org/10.1111/ifd.12541

http://archimer.ifremer.fr/doc/00350/46132/

(c) 2016 John Wiley \& Sons Ltd

\title{
Viral encephalopathy and retinopathy in aquaculture: a review
}

\author{
Doan $Q K^{1,2,{ }^{*} \text {, Vandeputte Marc }}{ }^{1,3}$, Chatain Beatrice ${ }^{1}$, Morin T. ${ }^{4}$, Allal Francois ${ }^{1}$
}

${ }^{1}$ Ifremer, UMR 9190 MARBEC; Palavas-les-Flots ,France

2 TNU, Thai Nguyen University of Agriculture and Forestry (TUAF); Quyet Thang Commune Thai Nguyen City, Vietnam

3 INRA, GABI; AgroParisTech; Université Paris-Saclay; Jouy-en-Josas, France

${ }^{4}$ Anses, Ploufragan-Plouzané Laboratory; Unit Viral Diseases of Fish; Plouzané ,France

*Corresponding author : Q. K. Doan, email address : doanquockhanh@tuaf.edu.vn

\begin{abstract}
:
Viral encephalopathy and retinopathy (VER), otherwise known as viral nervous necrosis (VNN), is a major devastating threat for aquatic animals. Betanodaviruses have been isolated in at least 70 aquatic animal species in marine and in freshwater environments throughout the world, with the notable exception of South America. In this review, the main features of betanodavirus, including its diversity, its distribution and its transmission modes in fish, are firstly presented. Then, the existing diagnosis and detection methods, as well as the different control procedures of this disease, are reviewed. Finally, the potential of selective breeding, including both conventional and genomic selection, as an opportunity to obtain resistant commercial populations, is examined.
\end{abstract}

\section{Introduction}

Although there is presently no strong evidence highlighting a possible raise of fish disease outbreaks due to climate change, increasing temperatures are expected to induce the spread of pathogens towards higher latitudes and to provoke negative impacts on fish physiology (Cochrane et al. 2009). Among others, the viral encephalopathy and retinopathy (VER), otherwise known as viral nervous necrosis (VNN), is considered one of the most serious viral threats for almost all marine aquaculture fish species, and requires a special focus due to the fact that outbreaks mostly happen in warm conditions. This disease, detected in at least 70 cultured or wild marine and fresh water species, already caused serious economic losses in the aquaculture industry in the past decades, and we can anticipate larger impacts of this disease because of global warming. 
37 No simple and effective procedures are available to treat this disease in fish. It is, therefore, 38 important to develop tools and set up new approaches to limit the occurrence and impacts of 39 VNN episodes in aquaculture farms.

To stress that need, we present here an extensive review about VNN disease in aquaculture, including the features of the virus, the available procedures to control this disease, and the potential of selective breeding and genomic selection for resistance to viral diseases, as a prospective way to prevent VNN disease in fish.

\section{NERVOUS NECROSIS VIRUS}

The causative agent of VNN, the Nervous Necrosis Virus, was classified as a member of the Nodaviridae family (Mori et al. 1992) which contains two genera: alphanodavirus and betanodavirus (Van Regenmortel et al., 2000). The species of the first genus were originally isolated from insects (figure 1), but appear to infect both vertebrates and invertebrates, and to cause the death of insect and mammalian hosts (Adachi et al. 2008). Betanodaviruses usually affect the nervous system of marine fish, leading to behavioral abnormalities and extreme high mortalities (Munday et al. 2002). In mammals, the pathogenicity of betanodaviruses is poorly reported, but mice have been demonstrated as non-susceptible, and human cells as not permeable to that genus (Adachi et al. 2008). Recently, a new emerging disease, the white tail disease (WTD) which affects the giant freshwater prawn and the whiteleg shrimp Penaeus vannamei has been demonstrated to be caused by the Macrobrachium rosenbergii nodavirus (MrNV). Sequence analysis of this virus suggests the existence of a new genus, gammanodavirus, infecting crustaceans (Qian et al. 2003; Senapin et al. 2012 - figure 1).

\section{General morphology:}

Betanodavirus virions were first described as non-enveloped, spherical in shape, and have icosahedral symmetry, with a diameter around $25 \mathrm{~nm}$ and a capsid formed by 180 copies of a 
61 single protein of $42 \mathrm{Kda}$ (Mori et al. 1992). A similar virus of 20-34 $\mathrm{nm}$ in diameter was

62 detected in infected Asian sea bass Lates calcarifer larvae, striped jack Pseudocaranx dentex,

63 turbot Scophthalmus maximus, European sea bass Dicentrarchus labrax (Yoshikoshi \& Inoue

64 1990; Glazebrook et al. 1990; Bloch et al. 1991; Munday et al. 1992) and many various fish

65 species through the world were subsequently recorded to be infected by betanodaviruses

66 (Munday et al. 2002; Shetty et al. 2012).

67 Molecular structure:

68 Betanodavirus contains a bi-segmented genome composed of two single-stranded, positive69 sense RNA molecules (Mori et al. 1992). The sequence of RNA1 is about $3.1 \mathrm{~kb}$, and includes 70 an open reading frame (ORF) encoding a RNA-dependent RNA polymerase (RdRp) of 110 $71 \mathrm{kDa}$ catalyzing the replication of the virus, also named protein A (Nagai \& Nishizawa 1999). 72 The sequence of RNA2 $(1.4 \mathrm{~kb})$ encodes the capsid protein $(37 \mathrm{kDa})$ which may have a 73 function in the induction of cell death (Guo et al. 2003). In addition, during the virus 74 replication, a sub-genomic RNA (RNA3) is synthesized from the 3'-terminus of RNA1 (Ball 75 \& Johnson 1999). This RNA3 encodes two other nonstructural proteins, B1 (111 amino acids) 76 and B2 (75 amino acids). Protein B1 displays anti-necrotic property enhancing the viability of 77 viral host cell (Sommerset \& Nerland 2004). Protein B2 is an inhibitor of host RNA silencing 78 in either alphanodavirus or betanodavirus, but could also promote mitochondrial 79 fragmentation and cell death induced by hydrogen peroxide production ( $\mathrm{Su}$ et al. 2014).

\section{Classification:}

81 Betanodavirus was described for the first time from infected larval stripped jack. The name 82 striped jack nervous necrosis virus (SJNNV) was consequently adopted (Mori et al. 1992). 83 Subsequently other agents of VNN were isolated from diseased fish species (Munday et al. 84 2002). The first comparative studies between viral strains isolated from different marine fish 85 species were done in the middle of the 1990s, where Nishizawa et al. reported the sequence of 
SJNNV and four different fish Nodaviruses as well as four different insect Nodaviruses (Nishizawa et al. 1995). From a phylogenetic analysis of the RNA2 T4 variable region, betanodaviruses were classified into four different species designed as the SJNNV-type, the barfin flounder nervous necrosis virus (BFNNV)-type, the red-spotted grouper nervous necrosis virus (RGNNV)-type, and the tiger puffer nervous necrosis virus (TPNNV)-type (Nishizawa et al. 1997). These species partially correlate with three different serotypes determined from virus neutralization using polyclonal antibodies (serotype A for SJNNV species, B for TPNNV species and C for BFNNV and RGNNV species) (Morit et al. 2003). Each species corresponds to different host fish and different in vitro optimal growth temperatures (table 1). RGNNV is the most popular species because a variety of fish species, distributed in warm-water, are affected (optimal growth temperature of $25-30^{\circ} \mathrm{C}$ ) (Asian sea bass, European sea bass, groupers...), whereas BFNNV is restricted to cold-water $\left(15-20^{\circ} \mathrm{C}\right)$ marine fish species (Atlantic halibut Hippoglossus hippoglossus, Atlantic cod Gadus morhua, flounders...) and TPNNV infects a single species (Tiger puffer Takifugu rubripes) at an intermediate temperature $\left(20^{\circ} \mathrm{C}\right)$. The SJNNV type was initially known to affect a few species cultured in Japan at $20-25^{\circ} \mathrm{C}$ (Iwamoto et al. 2000; Munday et al. 2002; Nishizawa et al. 1995; Toffan et al. 2016). However, it was also recently described in some fish species cultured in Southern Europe such as Senegalese sole Solea senegalensis in Spain, gilthead sea bream Sparus aurata and European sea bass in the Iberian Peninsula (Thiéry et al. 2004; Cutrín et al. 2007). This capacity to infect such warm water fish species is probably associated to reassortant RGNNV and SJNNV strains (Iwamoto et al. 2004; Toffolo et al. 2007; Panzarin et al. 2012; Toffan et al. 2016, see also Phylogenetic relationshipc paragraph). Phylogenetic analysis of betanodaviruses was also made based on the $\mathrm{T} 2$ region, which covers a larger RNA2 sequence than T4 (Chi et al. 2003; Johansen et al. 2004). This taxonomy has been used to genetically characterized new isolates in various fish species as well as in different areas 
111 (Aspehaug et al. 1999; Starkey et al. 2000; Dalla Valle et al. 2001; Tan et al. 2001; Skliris et 112 al. 2001; Johnson et al. 2002; Chi et al. 2003; Gagné et al. 2004; Sommerset \& Nerland 2004;

113 Thiéry et al. 2004; Johansen et al. 2004; Ransangan \& Manin 2012; Vendramin et al. 2013).

114 Because NNV is detected in many new species as well as new regions, description of new 115 isolates and sequences are regularly published and could lead to evolution in the classification

116 (table 1). For example, an additional genotype including a turbot betanodavirus strain

117 (TNNV) was described in 2004. This species is currently awaiting classification (Johansen et 118 al. 2004).

119 An alternative classification has been proposed (Thiéry et al. 2004). However, this numerical

120 nomenclature (cluster I, II, III and IV), independent from the host species origin, is not 121 extensively used because viruses from different clusters could infect a same host species, for 122 example European sea bass (Thiéry et al. 1999) and the classification was not consistent with 123 geographical areas (Dalla Valle et al. 2001; Thiéry et al. 2004; Cutrín et al. 2007).

\section{Phylogenetic relationships:}

125 Among the different species of betanodaviruses, amino acid sequences of RdRp protein and 126 capsid protein share 87 to $99 \%$ and 77 to $100 \%$ of identity respectively ( 82 to $98 \%$ for the 127 complete RNA1 nucleic sequence and 76 to $99 \%$ for the RNA2 segment (Okinaka \& Nakai 128 2008). The topology of phylogenetic trees based on RNA1 and RNA2 distinguishes several 129 clades, suggesting a high diversity despite relatively strong purifying selection on most 130 codons (Panzarin et al. 2012). This important variability can be explain by a significant 131 substitution rate but also by a re-assorting process specific to segmented viruses (Panzarin et 132 al. 2012). 


\section{DISTRIBUTION AND TRANSMISSION}

\section{Distribution:}

135 Viral encephalopathy and retinopathy is one of the most widespread viral disease of marine

136 fish species cultured worldwide. A large number of species have been reported to be affected, 137 especially larval and juvenile stages in which high mortalities were recorded (Munday et al.

138 2002; Shetty et al. 2012). Based on clinical signs, VNN disease has been documented since 1391985 in Japanese parrotfish Oplegnathus fasciatus larvae and juveniles in Japan, while the 140 pathogen was first observed in the brain of reared Japanese parrotfish (Yoshikoshi \& Inoue 141 1990). Three years later, it was recorded in European sea bass produced in Martinique (West 142 Indies, France) and French Mediterranean (Breuil et al. 1991). Since then, similar clinical 143 signs with encephalitis associated with picorna-like viral particles were observed in the Asian 144 sea bass Lates calcarifer cultured in Australia (Glazebrook et al. 1990; Munday et al. 2002), 145 as well as in turbot Scopthalmus maximus (Bloch et al. 1991), red-spotted grouper 146 Epinephalus akaara (Nishizawa et al. 1995), striped jack Pseudocaranx dentex (Mori et al. 147 1992), Japanese flounder Paralichthys olivaceus (Nishizawa et al. 1995), tiger puffer Takifugu 148 rublipes, kelp grouper Epinephelus moara (Munday et al. 2002) and barfin flounder Verasper 149 moseri in Japan (Nishizawa et al. 1995), and recently in golden grey mullet Liza aurata and 150 leaping mullet Liza saliens in the Caspian Sea (Zorriehzahra et al. 2016). Infections caused by NNV have been detected all around the world, with the notable

152 exception of South America (Crane \& Hyatt 2011; Shetty et al. 2012). It was the cause of 153 mass mortality in Atlantic halibut in Norway and Scotland (Grotmol et al. 1997; Starkey et al. 154 2000) and in juvenile greasy grouper Epinephelus tauvina in Singapore (Hegde et al. 2002) 155 and in groupers in Taiwan (Chi et al. 1997). Betanodaviruses have been the cause of high 156 economical losses in aquaculture industry throughout the Mediterranean area. Mass 
mortalities have been repeatedly recorded since 1991 on larvae and juvenile stages in

158 European sea bass in France (Breuil et al. 1991) as well as on grow-out size sea bass in

159 Greece, Italia and Tunisia (Le Breton et al. 1997; Bovo et al. 1999; Thiery et al. 2004;

160 Haddad-Boubaker et al. 2013). Grey mullet Mugil cephalus, red drum Sciaenops ocellatus,

161 and barramundi cultured in Israel were also reported to be affected by NNV (Ucko et al.

162 2004). Farmed Senagalese sole Solea senegalensis were reported as infected by RGNNV and

163 SJNNV in Spain (Thiery et al. 2004, Hodneland et al. 2011). More recently, RGNNV, SJNNV

164 genotypes and reassortant RGNNV/ SJNNV and SJNNV/RGNNV viruses have been reported

165 to infect several fish species (European sea bass, sea bream, Senegalese sole) in

166 Mediterranean Sea (Toffolo et al. 2007; Olveira et al. 2009; Hadda-Boubaker et al. 2013;

167 Panzarin et al. 2012; Toffan et al. 2016). A strain belonging to the RGNNV species caused

168 mass mortality in white sea bass Atractoscion nobilis reared in South California in 1999

169 (Curtis et al. 2001). NNV was also found in Atlantic cod and haddock Melanogrammus

170 aeglefinus juvenile stages on the Atlantic coast of North America (Johnson et al. 2002).

171 Furthermore, betanodaviruses do not only affect reared fish species, but have also been found

172 in a variety of wild fish species, as reported in table 2.

173 Regarding environment, although NNV is mostly known for infecting aquatic animals in

174 marine and brackish water, the reports of freshwater species infected by NNV have been

175 increasing (table 2). NNV infection was observed in freshwater eel and catfish aquaculture

176 systems in Taiwan (Chi et al. 2003) as well as in other freshwater species including sturgeon

177 Acipenser gueldenstaedtii (Athanassopoulou et al. 2004), tilapia Oreochromis niloticus

178 (Bigarré et al. 2009), largemouth bass Micropterus salmoides, pike-perch Sander lucioperca,

179 striped bass x white bass, Morone saxatilis x Morone chrysops (Bovo et al. 2011), guppy

180 Poecilia reticulata (Hegde et al. 2003), Australian catfish Tandanus tandanus, and sleepy cod

181 Oxyeleotris lineolatus (Munday et al. 2002). Zebrafish Danio rerio and goldfish Carassius 
182 auratus were also found to be infected (Binesh 2013). Furthermore, the freshwater blenny

183 Salaria fluviatili, which is an endangered species endemic to watersheds of the Mediterranean

184 Basin, was also reported as affected by NNV (Vendramin et al. 2012). To date, the

185 susceptibility of Mandarin fish Siniperca chuatsi to RGNNV, an important economical

186 species in freshwater aquaculture in China, has been demonstrated (Tu et al. 2016). At

187 present, at least 70 host species belonging to 32 families of 16 orders have been described as

188 carriers of betanodavirus (table 2) and this disease is widely reported all over the world, with

189 the exception of South America.

\section{Transmission:}

191 NNV is characterized by both vertical and horizontal transmission (Munday et al. 2002, see

192 also figure 2). Vertical transmission was early described in a number of different fish species

193 where betanodaviruses were detected in broodstock gonads or in early larval stages with

194 typical symptomatic signs. It can occur from broodstock to larvae through germplasm,

195 including the eggs or genital fluids as reported in striped jack, in barfin flounder or in

196 European sea bass (Mushiake et al. 1994; Nishizawa et al. 1996; Mori et al. 1998; Watanabe

197 et al. 2000; Dalla Valle et al. 2000; Breuil et al. 2002).

198 Horizontal transmission is a very difficult route to control because betanodavirus can easily

199 spread during an outbreak via water but also rearing equipment (Mori et al. 1998; Watanabe et

200 al. 1998). Horizontal transmission has been experimentally demonstrated by several routes:

201 contact between healthy fish and diseased larvae (Arimoto et al. 1993), bathing fish in water

202 containing betanodavirus-infected tissue homogenates (Arimoto et al. 1993; Tanaka et al. 1998;

203 Grotmol et al. 1999), contamination using strains isolated from symptomatic fish (Koch

204 postulate) (Thiéry et al. 1997; Peducasse et al. 1999) or contact of healthy fish with

205 asymptomatic carriers (Skliris \& Richards 1999; Breuil et al. 2002). 
206 Once in the aquatic environment, betanodavirus can persist without host for a long time and 207 can be spread widely by tide, aquatic transport means or migration of the wild hosts (Gomez 208 et al. 2004; Gomez et al. 2008; Giacopello et al. 2013). As NNV was reported in sand worms 209 belonging to the family Nereidae (Liu et al. 2006a) but also in crabs and mussels (Gomez et al. 210 2008), several studies are carried out to clarify the existence of non-fish carriers or vectors of 211 NNV such as raw fish (trash fish), brine shrimp Artemia salina and mollusks used as feed for 212 marine culture (Gomez et al. 2010; Costa \& Thompson 2016). Commercial trade of aquatic 213 animals should also be regarded as an important potential source of virus diffusion (Gomez et 214 al. 2006).

\section{DIAGNOSIS/DETECTION}

\section{First diagnostic approaches:}

217 In the early 1990s, the structure of NNV was already clearly known but virus isolation using

218 cell lines was not successful. Therefore, the method of VNN diagnostic relied on the 219 observation of characteristic clinical signs. VNN is characterized by typical behavioral 220 abnormalities (erratic swimming patterns such as spiraling or whirling, lying down at the tank 221 bottom, rapid swimming, darker coloration...) associated to an impairment of the nervous 222 system (figure 3) (Yoshikoshi \& Inoue 1990; Breuil et al. 1991; Chi et al. 1997). Gross 223 pathology examination frequently reveals a hyperinflation of the swim-bladder and 224 hemorrhages on the brain tissue. The most common microscopical findings consist of 225 vacuolation and necrosis of nervous cells of the spinal cord, brain and/or retina, particularly in 226 larvae and juveniles stages. The infection is rarely accompanied by inflammatory processes.

227 In presence of these typical signs, diagnosis must be confirmed by a laboratory test. Electronic 228 microscopy allowed observation of virus particles free or membrane bound by endoplasmic 229 reticulum in cells collected from infected organs (brain, retina) and revealed icosahedral, non- 
230 enveloped viruses with a commonly reported diameter of 20-34 nm (Yoshikoshi \& Inoue 231 1990; Glazebrook et al. 1990; Breuil et al. 1991; Bloch et al. 1991; Mori et al. 1992; Grotmol 232 et al. 1997). Over two decades, the reference method to detect betanodavirus was isolation in 233 permissive cell culture (striped snakehead cells SSN-1 or E11) followed by immunological 234 (indirect fluorescent antibody test - IFAT, immunohistochemistry, enzyme-linked 235 immunosorbent assay - ELISA; Nuñez-Ortiz et al. 2016) or molecular identification (RT236 PCR, Nested RT-PCR, real time RT-PCR). However, cell culture is time consuming, requires 237 a great experience, and some NNV strains are not always easy to detect because of a poor 238 cultivability and/or the absence of induction of clear cytopathic effects. This is why molecular 239 methods, particularly real-time RT-PCR, have been increasingly used (Munday et al. 2002; 240 Shetty et al. 2012).

\section{Direct molecular methods:}

242 Numerous RT-PCR protocols have been described for the detection of VNN (table 3). The 243 first RT-PCR published designed a set of primers (F2/R3) directed against $430 \mathrm{bp}$ from 244 the T4 variable region of the RNA2 segment of a SJNNV strain isolated from striped jack 245 (Nishizawa et al. 1994). Later on, the same region was amplified from other isolates, such 246 as red-spotted grouper (Nishizawa et al. 1995). This test, recommended by the World 247 Organization for Animal Health (OIE) until 2006, was extensively used for routine 248 diagnostic and genotyping of betanodavirus and led to the current classification 249 (Nishizawa et al. 1995; Nishizawa et al. 1997). However, the sensitivity of this method is 250 not only limited by a low viral load but also by the genetic diversity of the T4 region that 251 leads to mismatches between the F2/R3 primers and their targets (Nishizawa et al. 1996; 252 Thiéry et al. 1997; Dalla Valle et al. 2001). In some cases, it has been illustrated that 253 betanodavirus in brain could be detected by immunohistochemistry whereas the same 254 samples were negative by RT-PCR (Thiéry et al. 1997). In addition, low or false positive 
255 as well as false negative results were reported in different fish species like striped jack, 256 barfin flounder, European sea bass, shi drum Umbrina cirrosa and gilthead sea bream 257 (Nishizawa et al. 1996; Mori et al. 1998; Thiéry et al. 1999; Watanabe et al. 2000; Dalla 258 Valle et al. 2000). To improve the performance of this test and take into account genetic 259 diversity reported in newly available sequences, further generations of tests were 260 developed. Primers specific to more conserved region of the RNA2 or allowing to 261 discriminate Mediterranean and Atlantic viral strains were published as well as Nested262 PCR approaches allowing to improve the sensitivity by at least 100 times (Thiéry et al. 263 1999; Dalla Valle et al. 2000). More recently, Bigarré and colleagues designed a new set of 264 primers in a highly conserved region (680 bp) named T6 in RNA2 which perfectly matches 265 with a wide range of published sequences and detects at least three of the five described 266 species namely RGNNV, SJNNV and BFNNV (Bigarré et al. 2010).

267 Since 2005, numerous real-time RT-PCR assays were developed to regularly adapt the primer 268 sets and probes to newly published sequences (Dalla Valle et al. 2005; Fenner et al. 2006a; 269 Panzarin et al. 2010; Hick \& Whittington 2010; Hodneland et al. 2011; Baud et al. 2015). 270 These Real-time RT-PCR assays, targeting RNA1 or RNA2, are now currently used for the 271 diagnosis of betanodavirus because they are less time consuming than classical approaches 272 and significantly decrease cross-contamination occurring during post amplification procedures 273 (Hick \& Whittington 2010; Hodneland et al. 2011). Recently, a one-step generic TaqMan ${ }^{\circledR}$ 274 method targeting sequences found in a vast majority of known viral genotypes was validated 275 and efficiently used to detect NNV in different geographic regions and host species (Panzarin 276 et al. 2010; Baud et al. 2015), and an optimized loop-mediated isothermal amplification has 277 been developed to detect NNV in Epinephelus septemfasciatus (Hwang et al. 2016). This last 278 method showed improved sensitivity compared to PCR. 
279 Detection of different NNV species coexisting in the same host is still complex and may require 280 a combination of approaches (Lopez-Jimena et al. 2010). An ubiquitous assay detecting all 281 species would be desirable, but because of the high genetic diversity of betanodavirus, selection 282 of specific and wide spectrum primers allowing the detection of all possible variants still 283 remains a big challenge (Hodneland et al. 2011).

\section{Indirect serological methods:}

285 Serological investigations have been developed for several viral fish diseases but only few of 286 them are used for routine surveillance, despite the fact that diseases survivors often become 287 latent carriers with significant antibody response. The major reasons for this are poor 288 knowledge on the kinetics of the antibody response in fish at various water temperatures and 289 lack of validation data. Nevertheless, several ELISA or serum neutralization tests described 290 and improved over time proved their efficiency to detect antibodies specific to VNN 291 (Watanabe et al. 1998; Huang et al. 2001; Fenner et al. 2006b; Scapigliati et al. 2010; Choi et 292 al. 2014; Jaramillo et al. 2016b). For ELISA tests, the determination of the cut-off point is 293 critical to make the distinction between virus free status and viral infection. These indirect 294 methods are routinely used by several fish farms to regularly screen breeders. They have the 295 advantage to be no-lethal and safe for fish, and allow a regular screening of the VNN 296 serological status of a population at an individual level (Breuil \& Romestand 1999; Watanabe 297 et al. 2000; Breuil et al. 2002; Breuil et al. 2001; Jaramillo et al. 2016a; Nuñez-Ortiz et al. 298 2016).

\section{CONTROL PROCEDURES}

300 There are no simple and effective procedures to treat the viral disease in fish once established.

301 Therefore, efforts were concentrated on the means and tools to prevent entry, diffusion and 
302 persistence of the virus, mostly strict hygiene, vaccination and eradication of infected

303 populations (Gomez-Casado et al. 2011; Shetty et al. 2012).

304 In hatcheries, an important route of virus entry is infected asymptomatic breeders (Mushiake et

305 al. 1994; Watanabe et al. 1998). Although ozonation can seemingly prevent NNV transmission

306 from infected broodstock, it is not fully efficient because betanodavirus is not only present on

307 the surface of the eggs but also inside the eggs, and can also penetrate the egg via

308 spermatozoa (Kuo et al. 2012). A positive point is that vertical transmission can be controlled

309 effectively in hatcheries by combining detection via serological tests (ELISA) to detect anti-

310 VNN specific antibodies (in the blood serum of broodstock) or/and sensitive RT-PCR assays to

311 recognize viral RNA (in the eggs or genital fluids), combined with the elimination of positive

312 individuals (Mushiake et al. 1994; Breuil \& Romestand 1999; Watanabe et al. 2000; Breuil et

313 al. 2002; Hodneland et al. 2011). Ozonation and ultra-violet light are also used to clean

314 fertilized eggs and control water quality during rearing larval and juvenile stages. Even if

315 treatment of larvae requires complicated procedures, these treatments appear effective to

316 prevent horizontal transmission (Arimoto et al. 1996; Watanabe et al. 1998; Grotmoll \&

317 Totlandl 2000). Although betanodaviruses can be prevent effectively in hatchery based on

318 manage betanodavirus-free broodstock and disinfect hatchery water, the fish can be infected

319 betanodaviruses from the environment when they are cultured at grow-out stages.

320 Vaccination has been considered as an effective procedure for controlling VNN disease. A

321 number of vaccines made with inactivated NNV, virus-like particles (VLPs), recombinant C

322 protein and synthetic peptides from the $\mathrm{C}$ protein have been tested (Gomez-Casado et al.

323 2011). Recombinant betanodavirus coat proteins expressed in Escherichia coli was firstly

324 proposed in different fish species like sevenband grouper Epinephelus septemfasciatus and

325 humpback grouper Cromileptes altivelis (Tanaka et al. 2001; Yuasa et al. 2002), turbot and

326 Atlantic halibut (Húsgarð et al. 2001; Sommerset et al. 2005). More recent constructions 
327 combined to artermia or Vibrio anguillarum induced significant levels of protection in larvae 328 of orange-spotted grouper Epinephelus coioides (Lin et al. 2007; Chen et al. 2011), and 329 enhanced virus-neutralizing antibody response was observed after immunisation at grow-out 330 stages with recombinant C protein (Sommerset et al. 2005). Virus-like particles have also 331 been developed to create a more effective procedure to control VNN disease (Thiéry et al. 332 2006; Liu et al. 2006b). To date, the efficiency of the pFNCPE42-DNA vaccine, which has 333 been developed using the capsid protein gene of an Indian isolate of fish nodavirus has been 334 illustrated in Asian sea bass with a high relative percent survival of $77.33 \%$ (Vimal et al. 335 2016). All these systems require to go through an injection. Consequently, they are only really 336 effective on grow-out size fish or to prevent vertical transmission in breeding, while the VNN 337 disease often occurs in early larval and juvenile stages at which the size of fish is too small to 338 allow vaccination by injection (Sommerset et al. 2005; Kai \& Chi 2008; Brudeseth et al. 339 2013). A water-delivery strategy (immersion) could represent a more interesting way of 340 control (Kai \& Chi 2008) but still needs to be improved.

341 The viral diversity of betanodavirus with at least four different species described is another 342 challenge to overcome for which DNA vaccines have numerous advantages compared to 343 traditional antigen vaccines (Gomez-Casado et al. 2011). However, no license has been 344 delivered to date for potential applications in commercial fish farms in some areas such as 345 Europe (Gomez-Casado et al. 2011; Brudeseth et al. 2013). The vaccine application is usually 346 expensive in fish and the protection generated often lasts for in short time because of the low 347 immune reactivity in early stages of life (Sommerset et al. 2005). For these disadvantages, 348 although a variety of vaccinations for NNV have been experienced (table 4), only one 349 inactivated RGNNV vaccine against NNV of sevenband grouper was commercialized in 350 Japan (Brudeseth et al. 2013). Nevertheless, work in progress to better understand the immune 351 mechanisms involved during NNV infection (Costa \& Thompson 2016; Carballo et al. 2016; 
$\mathrm{Wu}$ et al. 2016) will likely result in the near future in the improvement of the prophylactic

353 strategies, like the use of preventive administration of interferons at the larval stage (Kuo et al.

354 2016) or of ribavirin as antiviral agent (Huang et al. 2016).

\section{SELECTIVE BREEDING TO NNV RESISTANCE: PROSPECTIVE}

\section{PROCEDURE}

357 While selective breeding programs have been mostly targeting productivity traits like e.g. 358 growth and carcass quality (Gjedrem \& Thodesen 2005), disease resistance remains a major 359 goal for breeding programs, as mortality caused by diseases is a major threat to aquaculture.

360 Selecting fish with increased resistance to specific diseases seem to be feasible for most 361 diseases (reviewed by Gjedrem 2015). Moreover, it provides cumulative and permanent 362 improvement of resistance over generations at the population level, thus providing unique 363 benefits when compared to other methods. Due to its cost however, the selective breeding 364 strategy toward resistant cultured fish is particularly interesting when other prevention 365 methods are inefficient. The use of resistant populations would not only reduce outbreaks, but 366 also lower the cost of fish production (Ødegård et al. 2011; Yáñez et al. 2014a).

\section{Disease resistance heritability in fish}

368 Improving a trait by artificial selection basically requires sufficient genetic variation for this 369 trait in the population. Genetic variation in disease resistance has been observed for many 370 diseases, and most likely variation would be seen for all diseases (Bishop \& Woolliams 2014).

371 While heritability for resistance to viral diseases have been estimated in many species, it 372 remains that most studies have been conducted in salmonids.

373 The heritability of resistance to viral diseases has been shown to be moderate to high in fish 374 (table 5). In the first place, resistance to VHS virus (VHSV) was found highly heritable 
$375\left(\mathrm{~h}^{2}=0.57-0.63\right)$ in rainbow trout (Oncorhynchus mykiss) when assessed by mortality (Dorson 376 et al. 1995; Henryon et al. 2005), while it was little heritable $\left(\mathrm{h}^{2}=0.11 \pm 0.10\right.$ and 0.13$)$ when 377 resistance was assessed as the time until death following challenge (Henryon et al. 2002; 378 Henryon et al. 2005). Moderate to high heritabilities have been estimated for Infectious 379 Salmon Anaemia Virus (ISAV), ranging from 0.13 to 0.26 on the observable scale and from 3800.19 to 0.40 on the liability scale (Gjøen et al. 1997; Ødegård et al. 2007a; Olesen et al., 2007; 381 Kjøglum et al. 2008; Gjerde et al. 2009), while the heritability of Infectious Pancreatic 382 Necrosis Virus (IPNV) resistance was also found moderate to high, ranging between 0.16 and 3830.55 (Guy et al. 2006; Guy et al. 2009; Wetten et al. 2007; Kjøglum et al. 2008). Other viral 384 diseases in fish also display moderate to high heritability, such as resistance to salmon 385 pancreases disease virus (SPDV) in Atlantic salmon (Salmo salar) with a liability scale 386 estimate of $0.21 \pm 0.05$ (Norris et al. 2008), and koi herpesvirus (KHV) resistance $387 \quad\left(\mathrm{~h}^{2}=0.79 \pm 0.14\right)$ in common carp (Cyprinus carpio) (Ødegård et al. 2010a).

388 To date, a high heritability for NNV has been demonstrated, but only in Atlantic cod 389 (Ødegård et al. 2010b; Bangera et al. 2011; Bangera et al. 2013). Ødegård et al. (2010b) 390 compared the NNV resistance of three different groups of Atlantic cod including Norwegian 391 coastal cod (CC), Northeast Atlantic cod (NEAC) and their F1 crossbreds. They showned 392 that the highest survival was obsevered in CC (56\%), followed by crosses (31\%), 393 whereas the survival rate of NEAC was only $10 \%$. The estimated heritability for NNV 394 resistance was high on the observed scale $(0.43 \pm 0.07)$ and very high on the underlying scale 395 (0.75 \pm 0.11$)$ (Ødegård et al. 2010b). Besides that, a high heritability for NNV resistance was 396 also recorded $(0.68 \pm 0.14)$ by Bangera et al. (2011) who later on reported an extremely high 397 heritability (0.91 using a cure model) for NNV resistance in the same species (Bangera et al., 398 2013). In addition, the genetic correlation between resistance to NNV and to a bacterial 399 disease (Vibriosis) was shown not to significantly differ from zero (Bangera et al. 2011). This 
400 lack of correlation is similar to other studies in salmonids which estimated the genetic

401 correlation between resistance against ISAV and furuculosis (Gjøen et al. 1997; Ødegård et al.

402 2007b; Kjøglum et al. 2008) or VHSV and enteric red-mouth disease as well as rainbow trout

403 fry syndrome (Henryon et al. 2005).

404 The heritability of resistance to viral disease is moderate to high in almost exsisting studies,

405 indicating viral disease resistance can be improve significantly based on selective breeding in

406 farmed fish - and the prospects for NNV resistance are specially good, due to the high to very

407 high heritability estimate (only in Atlantic cod for the moment).

\section{Genetic Selection to Viral Disease Resistance in Fish}

409 Following promising heritability estimates, experimental selective breeding for disease

410 resistance has been undertaken and shown to be an effective solution to prevent the outbreak

411 of viral diseases in farmed fish. In the end of the1980s, selective breeding for resistance to

412 VHSV in rainbow trout was successfully tried in France, resulting in an improved resistance

413 in the second generation, with 0 to $10 \%$ mortality, compared to 70 to $90 \%$ in the control group

414 (Dorson et al. 1995). In Denmark, relatively VHSV-resistant broodstock were selected from a

415 challenge test, and used to produce first and second generation gynogenetic offspring (Bishop

416 \& Woolliams 2014). Salmon commercial breeding programs have included resistance to

417 furunculosis, ISAV and IPNV since 1993 in Norway (Gjøen et al. 1997; Moen et al. 2009;

418 Yáñez et al. 2014). The effective of selective breeding for IPNV resistance in Atlantic salmon

419 was illustrated by Storset et al. (2007), where the fish belonging to low and high resistant

420 families were challenged in both freshwater and seawater and obtaining significant differences

421 in mortalities, which ranged from $29-32 \%$ in high resistance families to $66-79 \%$ in low 422 resistance families in both freshwater and seawater. 


\section{Quantitative Trait Loci mapping for resistance to viral diseases}

424 Identifying portions of the genome called Quantitative Trait Loci (QTLs) linked to the disease

425 resistance phenotype is expected to speed up the selection process by using Marker-Assisted

426 selection (Massault et al. 2008; Bishop \& Woolliams 2014).

427 Most of the QTLs identified for resistance to viral diseases in cultured fish have been 428 identified in Salmonids, the most successful example being the IPNV resistance QTL. Three highly significant QTLs were first identified using microsatellite and AFLP markers in a backcross of rainbow trout strains displaying high and low resistance to IPNV, each explaining $13-15 \%$ of the phenotypic variance of the total phenotypic variance (Ozaki et al. 2001; Ozaki et al. 2007). For IPNV resistance in Atlantic salmon, even more significant QTLs have been identified (Houston et al. 2008; Houston et al. 2010; Moen et al. 2009; Gheyas et al. 2010), leading to a breakthrough with respect to the implementation of QTL in salmon breeding. A first QTL, producing a 75\% difference in IPNV mortality between the alternative homozygotes, was mapped to linkage group 21 (LG21) (Houston et al. 2008). The same QTL was independently reported in 2009 in Norwegian population, where it explained $29 \%$ of the phenotypic variance (Moen et al. 2009). Gheyas et al. (2010) confirmed the resistance effect of the QTL from LG21 at the fry stage in freshwater, with a QTL heritability of $0.45 \pm 0.07$ on the liability scale and $0.25 \pm 0.05$ on the observed scale. In one family, $100 \%$ of the

441 offspring homozygous for the susceptible QTL alleles died, whereas 100\% of the offspring 442 homozygous for the resistant QTL alleles survived (Gheyas et al. 2010).

443 QTLs for resistance to other viral diseases in Salmonids include QTLs for IHNV resistance 444 (Palti et al. 1999; Palti et al. 2001; Miller et al. 2004; Rodriguez et al. 2004; Barroso et al. 445 2008), ISAV resistance (Moen et al. 2004; Moen et al. 2007), VHSV resistance (Verrier et al. 446 2013) and Salmonid Alphavirus (SAV) resistance (Gonen et al. 2015). Like for IPNV, the 447 IHNV QTLs explained a high part of the phenotypic variance (up to $32.5 \%$ according to 
448 Barroso et al. 2008), while it was more limited for the ISAV QTL (6\% of the phenotypic 449 variance, Moen et al. 2007). In both cases, a significant association with MHC alleles was 450 later demonstrated (Palti et al. 2001; Miller et al. 2004 for IHNV; Kjøglum et al. 2006 for 451 ISAV).

452 About NNV resistance, five genome-wide significant QTLs, explaining 68\% of the 453 phenotypic variance for resistance, detected based on 161 microsatellite markers in Atlantic 454 cod (Baranski et al. 2010), a very high amount, which can be paralleled to the very high 455 heritability of NNV resistance reported earlier. A later analysis with a $12 \mathrm{~K}$ SNP array 456 confirmed both the high proportion of variance explained by genomic markers, and the 457 location of three of these QTLs (Yu et al. 2014). The latest QTLs related to NNV resistance 458 identified based on 146 microsatellite markers in Asian sea bass. In that study, Liu et al. 2016 459 detected multiple QTLs for NNV resistance and survival time. However, a few proportion of 460 the phenotypic variation were explained by those QTLs (2.2-4.1\% for resistance and 2.2-3.3\% 461 for survival time).

462 Taken altogether, these information about the QTLs for resistance to viral diseases in fish are 463 very promising for increasing the rate of resistance through selective breeding, especially as in 464 many cases QTLs seem to be of large effect, which gives good prospects to improve genetic 465 resistance in a relatively short term, by direct marker-assisted selection or by introgression of 466 QTLs from different populations (Bishop \& Woolliams 2014). This possibility may especially 467 develop as SNP markers become more and more available and affordable, due to their 468 abundance and to fast technological developments, making both detection and selection of 469 QTLs more economically realistic. 


\section{Markers-assisted Selection (MAS) and Genomic Selection (GS) For Viral Disease in Fish}

Breeding resistant fish based on survivors of challenge trials, although sometimes done, is generally undesirable due to the risk of vertical transmission of the pathogen. The usual way to overcome this limitation in conventional breeding is to perform sib selection. In sib selection, breeding candidates are kept in a pathogen-free environment, and selected using family-wise estimated breeding values obtained from the survival of fish from the same families challenged with the disease. Another possible way to select resistant fish without exposing them to the pathogen is the identification of relevant QTL and the application of molecular markers for Marker Assisted Selection (MAS), or the direct use of genotype data to perform Genomic Selection (GS). With both methods, fish are selected based only on their genotype, either at specific QTL-linked markers in the case of MAS, or at many markers, which may not all be linked to the resistance in the case of GS. This allows to avoid any contact between the breeding candidate and the pathogen. In terms of efficiency, the advantage of MAS compared to conventional selection is expected to be largest when the trait under selection has a low heritability - which is not generally the case for viral disease resistance in fish - or when the trait is not measured on the breeding candidates - which conversely is typically the case for disease resistance (Gjedrem 2015). With simulated traits and populations, the accuracy of selection was improved significantly by using MAS, compared to non-MAS in selective breeding in aquaculture (Sonesson 2007). Practical application of MAS in aquaculture breeding has been implemented for IPNV resistance Atlantic salmon in both Norwegian (Moen et al. 2009) and Scottish populations (Houston et al. 2010). Still, the limitation of MAS is that it requires prior knowledge of alleles that are associated with the traits of interest, which moreover have to be validated in the specific populations or even families under selection. Furthermore, MAS exploits only a limited part 
494 of the genetic differences between individuals, as it does not exploit the polygenic background

495 variation, which may account for a large part of the genetic variance (Meuwissen et al. 2016).

496 An alternative approach for more polygenic traits is genomic selection. In this approach, 497 genetic markers are used to cover the whole genome so that all QTL, even non statistically 498 significant, are in linkage disequilibrium (LD) with at least one marker and selection is based 499 on genetic values predicted from all the markers (Meuwissen et al. 2001; Goddard \& Hayes 500 2007; Meuwissen et al. 2016). The availability of high density SNP arrays in livestock and 501 now increasingly in aquaculture species is making both genomic selection and genome-wide 502 association studies (GWAS) feasible. GWAS approaches allow studies of the genetic 503 architecture of quantitative traits, while genomic selection will improve the accuracy of 504 selection in breeding programs (Houston et al. 2014). In terms of present realization of these 505 approaches, GWAS showed highly significant association of several SNPs with resistance to 506 IPNV, as well as population level linkage-disequilibrium in salmon commercial populations 507 (Houston et al. 2012). The implementation of such approaches is dependent on the 508 development of SNP genotyping arrays, which for the time being have mostly been developed 509 in salmonids, like a $130 \mathrm{~K}$ array for farmed and wild Atlantic salmon in Scotland (Houston et 510 al. 2014), $160 \mathrm{~K} \mathrm{SNP} \mathrm{markers} \mathrm{were} \mathrm{validated} \mathrm{based} \mathrm{on} 200 \mathrm{~K} \mathrm{SNPs}$ applied to different wild 511 and farmed populations of Atlantic salmon (Europe population, North America population 512 and Chile population) (Yáñez et al. 2014b), and a 57 K SNP chip which is now available for 513 rainbow trout (Palti et al. 2014). A 12K SNP array has been also developed in Atlantic cod, 514 containing markers distributed across all 23 chromosomes (Yu et al. 2014). It was already 515 used in a GWAS analysis for NNV resistance which revealed 29 genome-wide significant 516 SNPs for binary survival, and 36 genome-wide significant SNPs for number of days fish 517 survived, as well as high genomic heritabilities of 0.49 and 0.81 for the same traits, 518 respectively (Bangera et al. 2014). Identification of SNPs is being done in other species for 
519 which NNV resistance is a key issue, such as European sea bass (Tine et al. 2014; 520 Palaiokostas et al. 2015) or Asian sea bass (Wang et al, 2015), which is promising for the 521 development of GWAS or GS for NNV resistance in those species.

\section{CONCLUSION}

523 Viral encephalopathy and retinopathy is widespread all over the world except in South

524 America. While many of the main marine species in aquaculture are affected by this disease, 525 no simple and effective procedures are available to treat it. Even though VNN can be prevented 526 in hatcheries based on efficient diagnostic methods to monitor the breeders and biosecurity 527 measures during hatchery rearing, this disease still occurs on grow-out sites. Vaccination may 528 be an efficient way to prevent disease occurrence, but because of the specific drawbacks of 529 present vaccination methods and the difficulty to efficiently protect early larval stages, this tool 530 is not fully effective in the case of VNN. Selective breeding has been demonstrated as an 531 effective solution to select resistant aquaculture populations for several diseases, and new 532 genomics based methods allow to foresee even higher efficiency of selective breeding for 533 disease resistance in the near future. However, to reach the expectations of a practical 534 genomic selection, more genetic resources and more advanced studies are required for the vast 535 majority of aquaculture species affected by NNV.

\section{ACKNOWLEDGMENT}

537 This work was carried out in the frame of the FUI project RE-SIST funded by BPI-France and 538 région Languedoc-Roussillon, with a $\mathrm{PhD}$ grant of DOAN Quoc Khanh supported by the 539 Vietnamese government. 


\section{REFERENCES}

542 Adachi K., Ichinose T., Watanabe K., Kitazato K. \& Kobayashi N. (2008) Potential for the

543

544

545

546

547

548

549

550

551

552

553

554

555

556

557

558

559

560

561

562

563

564

565

566

567

568

569

570

571

572

573

574

575

576

577

578

579

580

581

replication of the betanodavirus red-spotted grouper nervous necrosis virus in human cell lines. Archives of Virology 153, 15-24.

Arimoto M., Sato J., Maruyama K., Mimura G. \& Furusawa I. (1996) Effect of chemical and physical treatments on the inactivation of striped jack nervous necrosis virus (SJNNV). Aquaculture 143, 15-22.

Arimoto M., Mori K., Nakai T., Muroga K. \& Furusawa, I. (1993) Pathogenicity of the causative agent of viral nervous necrosis disease in striped jack (Pseudocaranx dentex (Bloch \& Schneider)). Journal of Fish Diseases 16, 461-469.

Aspehaug V., Devold M. \& Nylund A. (1999) The phylogenetic relationtionship of nervous necrosis virus from halibut (Hippoglossus hippoglossus). Fish Pathology 19, 196-202.

Athanassopoulou F., Billinis C. \& Prapas T. (2004) Important disease conditions of newly cultured species in intensive freshwater farms in Greece: first incidence of nodavirus infection in Acipenser sp. Diseases of Aquatic Organisms 60, 247-52.

Ball L.A. \& Johnson K.L. (1999) Reverse genetics of nodavirus. Advanced in Virus Research 53, 229-244.

Bangera R., Baranski M. \& Lien S. (2014) A genome-wide association study for resistance to viral nervous necrosis in Atlantic cod using a $12 \mathrm{~K}$ single nucleotide polymorphism array. Proceedings, $10^{\text {th }}$ World Congress of Genetics Applied to Livestock Production, August $17^{\text {th }}$ $22^{\text {th }}, 2014$, Vancouver, BC, Canada.

Bangera R., Ødegård J., Nielsen H.M., Gjøen H.M. \& Mortensen A. (2013) Genetic analysis of vibriosis and viral nervous necrosis resistance in Atlantic cod (Gadus morhua L.) using a cure model. Journal of Animal Science 91, 3574-3582.

Bangera R., Ødegård J., Præbel A.K., Mortensen A. \& Nielsen H.M. (2011) Genetic correlations between growth rate and resistance to vibriosis and viral nervous necrosis in Atlantic cod (Gadus morhua L.). Aquaculture 317, 67-73.

Baranski M., Præbel A.K., Sommer A., Kirste K.H. \& Wesmajervi M. (2010) Major quantitative trait loci for viral nervous necrosis resistance in Atlantic cod (Gadus morhua L.). Proceedings, $9^{\text {th }}$ World Congress of Genetics Applied to Livestock Production, August $1^{\text {th }}-6^{\text {th }}$, 2010, Leipzig, Germany.

Barroso R.M., Wheeler P.A., LaPatra S.E., Drew R.E. \& Thorgaard G.H. (2008) QTL for IHNV resistance and growth identified in a rainbow (Oncorhynchus mykiss) $\times$ Yellowstone cutthroat (Oncorhynchus clarki bouvieri) trout cross. Aquaculture 277, 156-163.

Baud M., Cabon J., Salomoni A., Toffan A., Panzarin V. \& Bigarré L. (2015) First generic one step real-time Taqman RT-PCR targeting the RNA1 of betanodaviruses. Journal of Virological Methods 211, 1-7.

Bigarré L., Baud M., Cabon J., Crenn K. \& Castric J. (2010) New PCR probes for detection and genotyping of piscine betanodaviruses. Journal of Fish Diseases 33, 907-912.

Bigarré L., Cabon J., Baud M., Heimann M., Body A, Lieffrig F. \& Castric J. (2009) Outbreak of betanodavirus infection in tilapia (Oreochromis niloticus L.), in fresh water. 
582

583

584

585

586

587

588

589

590

591

592

593

594

595

596

597

598

599

600

601

602

603

604

605

606

607

608

609

610

611

612

613

614

615

616

617

618

619

620

621

622

623

Journal of Fish Diseases 32, 667-73.

Binesh C.P. (2013) Mortality due to viral nervous necrosis in zebrafish (Danio rerio) and goldfish (Carassius auratus). Diseases of Aquatic Organisms 104, 257-260.

Bishop S.C. \& Woolliams J.A. (2014). Genomics and disease resistance studies in livestock. Livestock Science 166, 190-198.

Bloch B., Gravningen K. \& Larsen J.L. (1991) Encephalomyelitis among turbot associated with a picornavirus-like agent. Diseases of Aquatic Organisms 10, 65-70.

Bonami J.R. \& Widada S.J. (2011) Viral diseases of the giant fresh water prawn Macrobrachium rosenbergii: a review. Journal of invertebrate pathology 106, 131-42.

Bovo G., Gustinelli A., Quaglio F., Gobbo F., Panzarin V., Fusaro A. \& Fioravanti M.L. (2011) Viral encephalopathy and retinopathy outbreak in freshwater fish farmed in Italy. Diseases of Aquatic Organisms 96, 45-54.

Bovo G., Nishizawa T., Maltese C., Borghesan F., Mutinelli F., Montesi F. \& De Mas S. (1999) Viral encephalopathy and retinopathy of farmed marine fish species in Italy. Virus Research, 63(1-2), 143-146.

Breuil, G., Pepin, J. F. P., Boscher, S. \& Thiery, R. (2002). Experimental vertical transmission of nodavirus from broodfish to eggs and larvae of the sea bass (Dicentrarchus labrax L.). Journal of Fish Diseases 25, 697-702.

Breuil G. \& Romestand B. (1999) A rapid ELISA method for detecting specific antibody level against nodavirus in the serum of the sea bass, (Dicentrarchus labrax L.): application to the screening of spawners in a sea bass hatchery. Journal of Fish Diseases 22, 45-52.

Breuil G., Bonamib J.R., Pepin J.F. \& Pichot Y. (1991) Viral infection (picorna-like virus) associated with mass mortalities in hatchery-reared sea-bass (Dicentrarchus labrax) larvae and juveniles. Aquaculture 97, 109-1 16.

Brudeseth B.E., Wiulsrød R., Fredriksen B.N., Lindmo K., Løkling K.E., Bordevik M., Steine N., Klevan A. \& Gravningen K. (2013) Status and future perspectives of vaccines for industrialised fin-fish farming. Fish and Shellfish Immunology 35, 1759-1768.

Carballo C., Garcia-Rosado E., Borrego J.J. \& Carmen Alonso M. (2016) SJNNV downregulates RGNNV replication in European sea bass by the induction of the type i interferon system Viruses infecting fish Alexandra Adams; Carlos P Dopazo. Veterinary Research 47:6.

Chen Y.M., Shih C.H., Liu H.C., Wu C.L., Lin C.C., Wang H.C. \& Lin J.H.Y. (2011) An oral nervous necrosis virus vaccine using Vibrio anguillarum as an expression host provides early protection. Aquaculture 321, 26-33.

Chi S.C., Shieh J.R. \& Lin S.J. (2003) Genetic and antigenic analysis of betanodaviruses isolated from aquatic organisms in Taiwan. Diseases of Aquatic Organisms 55, 221-228.

Chi S.C., Lo C.F., Kou G.H., Chang P.S., Peng S.E. \& Chen S.N. (1997) Mass mortalities associated with viral nervous necrosis (VNN) disease in two species of hatchery-reared grouper (Epinephelus fuscogutatus and Epinephelus akaara (Temminck \& Schlegel)). Journal of Fish Diseases 20, 185-193.

Choi B., Gye H.J., Oh M.J. \& Nishizawa T. (2014) Cell culture medium inhibits antigen binding used in an ELISA for detection of antibodies against nervous necrosis virus. Journal of Aquatic Animal Health 26,168-172. 
624 Ciulli S., Galletti E., Grodzki M., Alessi A., Battilani M. \& Prosperi S. (2007) Isolation and 625 genetic characterization of Betanodavirus from wild marine fish from the Adriatic sea. 626 Veterinary Research Communications 31, 221-224.

627 Cochrane K., De Young C., Soto D. \& Bahri T. (2009) Climate change implications for 628 fisheries and aquaculture: overview of current scientific knowledge. FAO Fisheries and Aquaculture Technical Paper. No. 530. Food and Agriculture Organization of the United Nations, Rome. and its host for the development of prophylactic measures for viral encephalopathy and retinopathy. Fish \& shellfish immunology 53, 35-49.

634 Crane M. \& Hyatt A. (2011) Viruses of fish: an overview of significant pathogens. Viruses, $6353(11), 2025-46$.

636 Curtis P.A., Drawbridge M., Iwamoto T., Nakai T., Hedrick R.P. \& Gendron A.P. (2001) Nodavirus infection of juvenile white sea-bass (Atractoscion nobilis) cultured in southern California: First record of viral nervous necrosis (VNN) in North America. Journal of Fish 639 Diseases 24, 263-271.

640 Cutrín J.M., Dopazo C.P., Thiéry R., Leao P., Olveira J.G., Barja J.L. \& Bandín I. (2007) 641 Emergence of pathogenic betanodaviruses belonging to the SJNNV genogroup in farmed fish 642 species from the Iberian Peninsula. Journal of Fish Diseases 30, 225-32.

643 Dalla Valle L., Toffolo V., Lamprecht M., Maltese C., Bovo G., Belvedere P. \& Colombo L. 644 (2005) Development of a sensitive and quantitative diagnostic assay for fish nervous necrosis 645 virus based on two-target real-time PCR. Veterinary Microbiology 110167-79.

646 Dalla Valle L., Negrisolo E., Patarnello P., Zanella L., Maltese C., Bovo G. \& Agripolis P.T. 647 (2001) Sequence comparison and phylogenetic analysis of fish nodaviruses based on the coat 648 protein gene. Archives of Virology 146, 1125-1137. Development of a sensitive diagnostic assay for fish nervous necrosis virus based on RT-PCR 651 plus nested PCR. Journal of Fish Diseases 23, 321-327.

652 Dorson M., Quillet E., Hollebecq M.G., Torhy C., Chevassus B. \& Selection B.C. (1995) 653 Selection of rainbow trout resistant to viral haemorrhagic septicaemia virus and transmission 654 of resistance by gynogenesis to cite this version: haemorrhagic septicaemia virus and 655 transmission. Veterinary Research 26, 361-368.

656 Fenner B.J., Thiagarajan R., Chua H.K. \& Kwang J. (2006a) Betanodavirus B2 is an RNA 657 interference antagonist that facilitates intracellular viral RNA accumulation. Journal of 658 Virology 80, 85-94.

659 Fenner B.J., Du Q., Goh W., Thiagarajan R., Chua H.K. \& Kwang J. (2006b) Detection of 660 betanodavirus in juvenile barramundi, Lates calcarifer (Bloch), by antigen capture ELISA. 661 Journal of Fish Diseases 29, 423-432.

662 Fukuda Y., Nguyen H.D., Furuhashi M. \& Nakai T. (1996). Mass Mortality of Cultured 663 Sevenband Grouper (Epinephelus septemfasciatus) associated with Viral Nervous Necrosis. 664 Fish Pathology 31, 165-170.

665 Furusawa R., Okinaka Y. \& Nakai T. (2006) Betanodavirus infection in the freshwater model 666 fish medaka (Oryzias latipes). The Journal of General Virology 87, 2333-2339. 
667 Gagné N., Johnson S.C., Cook-Versloot M., MacKinnon A.M. \& Olivier G. (2004) Molecular 668 detection and characterization of nodavirus in several marine fish species from the 669 northeastern Atlantic. Diseases of Aquatic Organisms 62, 181-189.

670 Gheyas A.A., Houston R.D., Mota-Velasco J.C., Guy D.R., Tinch A.E., Haley C.S. \& 671 Woolliams J.A. (2010) Segregation of infectious pancreatic necrosis resistance QTL in the 672 early life cycle of Atlantic salmon (Salmo salar). Animal Genetics 41, 531-536.

673 Giacopello C., Foti M., Bottari T., Fisichella V. \& Barbera G. (2013) Detection of viral 674 encephalopathy and retinopathy virus (VERV) in wild marine fish species of the South 675 Tyrrhenian Sea (Central Mediterranean). Journal of Fish Diseases 36, 819-821.

676 Gjedrem T. (2015) Disease resistant fish and shellfish are within reach: A Review. Journal of 677 Marine Science and Engineering 3, 146-153.

678 Gjedrem T. \& Thodesen J. (2005) Selection and breeding programs in aquaculture. 679 Dordrecht, The Netherlands: Springer 89-111.

680 Gjerde B., Evensen O., Bentsen H.B. \& Storset A. (2009) Genetic (co)variation of vaccine 681 injuries and innate resistance to furunculosis (Aeromonas salmonicida) and infectious salmon 682 anaemia (ISA) in Atlantic salmon (Salmo salar). Aquaculture 287, 52-58.

683 Gjøen H.M., Refstie T., Ulla O. \& Gjerde B. (1997) Genetic correlations between survival of 684 Atlantic salmon in challenge and field tests. Aquaculture 158, 277-288.

685 Glazebrook J.S., Heasman M.P. \& Beer S.W. (1990) Picorna-like viral particles associated 686 with mass mortalities in larval barramundi (Lates calcarifer Bloch). Journal of Fish Diseases 687 13, 245-249.

688 Goddard M.E. \& Hayes B.J. (2007) Genomic selection. Journal of Animal Breeding and 689 Genetics 124, 323-330.

690 Gomez D.K., Lim D.J., Baeck G.W., Youn H.J., Shin N.S., Youn H.Y. \& Park S.C. (2006) 691 Detection of betanodaviruses in apparently healthy aquarium fishes and invertebrates. Journal 692 of Vetarinary Science 7, 369-374.

693 Gomez D.K., Baeck G. W., Kim J.H., Choresca C.H. \& Park S.C (2008) Molecular detection 694 of betanodaviruses from apparently healthy wild marine invertebrates. Journal of Invertebrate 695 Pathology, 97(3), 197-202.

696 Gomez D.K., Mori K.I., Okinaka Y., Nakai T. \& Park S.C (2010) Trash fish can be a source 697 of betanodaviruses for cultured marine fish. Aquaculture, 302(3-4), 158-163.

Gomez D.K., Sato J., Mushiake K., Isshiki T., Okinaka Y. \& Nakai T. (2004) PCR-based 700 Journal of Fish Diseases 27, 603-608.

701 Gomez-Casado E., Estepa A. \& Coll J.M. (2011). A comparative review on European-farmed 702 finfish RNA viruses and their vaccines. Vaccine 29, 2657-2671.

703

704

705

706

707

708

Gonen S., Baranski M., Thorland I., Norris A., Grove H., Arnesen P., Bakke H., Lien S. \& Bishop S.C. (2015) Mapping and validation of a major QTL affecting resistance to pancreas disease (salmonid alphavirus) in Atlantic salmon (Salmo salar). Heredity 115, 405-414.

Grotmoll S. \& Totlandl G.K. (2000) Surface disinfection of Atlantic halibut Hippoglossus hippoglossus eggs with ozonated sea-water inactivates nodavirus and increases survival of the larvae. Diseases of aquatic organisms 39, 89-96. 
Grotmoll S., Berghl O. \& Totland G.K. (1999) Transmission of viral encephalopathy and retinopathy (VER) to yolk-sac larvae of the Atlantic halibut - Hippoglossus hippoglossus: occurrence of nodavirus in various organs and a possible route of infection. Diseases of Aquatic Organisms 36, 95-106.

Grotmol S., Totland G.K., Thorud K. \& Hjeltnes B.K. (1997) Vacuolating encephalopathy and retinopathy associated with a nodavirus-like agent: a probable cause of mass mortality of cultured larval and juvenile Atlantic halibut - Hippoglossus hippoglossus. Diseases of Aquatic Organisms 29, 85-97.

Grove S., Johansen R., Reitan L.J., Press C.M. \& Dannevig B.H. (2006) Quantitative investigation of antigen and immune response in nervous and lymphoid tissues of Atlantic halibut (Hippoglossus hippoglossus) challenged with nodavirus. Fish \& Shellfish Immunology 21, 525-539.

Guo Y.X., Wei T., Dallmann K. \& Kwang J. (2003) Induction of caspase-dependent apoptosis by betanodaviruses GGNNV and demonstration of protein $\alpha$ as an apoptosis inducer. Virology 308, 74-82.

Guy D.R., Bishop S.C., Woolliams J.A. \& Brotherstone S. (2009) Genetic parameters for resistance to Infectious Pancreatic Necrosis in pedigreed Atlantic salmon (Salmo salar) postsmolts using a Reduced Animal Model. Aquaculture 290, 229-235.

Guy D.R., Bishop S.C., Brotherstone S., Hamilton A, Roberts R.J., McAndrew B.J. \& Woolliams J.A. (2006) Analysis of the incidence of infectious pancreatic necrosis mortality in pedigreed Atlantic salmon, Salmo salar L., populations. Journal of Fish Diseases 29, 637647.

Haddad-Boubaker S., Bigarré L., Bouzgarou N., Megdich A., Baud M., Cabon J. \& Chéhida N.B. (2013) Molecular epidemiology of betanodaviruses isolated from sea bass and sea bream cultured along the Tunisian coasts. Virus genes, 46(3), 412-422.

Hegde A., Teh H.C., Lam T.J. \& Sin Y. M. (2003) Nodavirus infection in freshwater ornamental fish, guppy, Poicelia reticulate - comparative characterization and pathogenicity studies. Archives of Virology 148, 575-586.

Hegde A., Chen C.L., Qin Q.W., Lam T.J. \& Sin Y.M. (2002) Characterization, pathogenicity and neutralization studies of a nervous necrosis virus isolated from grouper, Epinephelus tauvina, in Singapore. Aquaculture 213, 55-72.

Henryon M., Berg P., Olesen N.J., Kjær T.E., Slierendrecht W.J., Jokumsen A. \& Lund I. (2005) Selective breeding provides an approach to increase resistance of rainbow trout (Onchorhynchus mykiss) to the diseases, enteric redmouth disease, rainbow trout fry syndrome, and viral haemorrhagic septicaemia. Aquaculture 250, 621-636.

Henryon M., Jokumsen A., Berg P., Lund I., Pedersen P.B., Olesen N.J. \& Slierendrecht W.J. (2002) Genetic variation for growth rate, feed conversion efficiency, and disease resistance exists within a farmed population of rainbow trout. Aquaculture 209, 59-76.

Hick P. \& Whittington R.J. (2010) Optimisation and validation of a real-time reverse transcriptase-polymerase chain reaction assay for detection of betanodavirus. Journal of Virological Methods 163, 368-377.

Hodneland K., García R., Balbuena J.A, Zarza C. \& Fouz B. (2011) Real-time RT-PCR detection of betanodavirus in naturally and experimentally infected fish from Spain. Journal 
752

753

754

755

756

757

758

759

760

761

762

763

764

765

766

767

768

769

770

771

772

773

774

775

776

777

778

779

780

781

782

783

784

785

786

787

788

789

790

791

792

793

of Fish Diseases 34, 189-202.

Houston R.D., Taggart J.B., Cézard T., Bekaert M., Lowe N.R., Downing A. \& Hamilton A. (2014) Development and validation of a high density SNP genotyping array for Atlantic salmon (Salmo salar). BMC Genomics 15:90.

Houston R.D., Davey J.W., Bishop S.C., Lowe N.R., Mota-Velasco J.C., Hamilton A. \& Taggart J.B. (2012) Characterization of QTL-linked and genome-wide restriction siteassociated DNA (RAD) markers in farmed Atlantic salmon. BMC Genomics 13:244.

Houston R.D., Haley C.S., Hamilton A., Guy D.R., Mota-Velasco J.C., Gheyas A.A. \& Bishop S.C. (2010) The susceptibility of Atlantic salmon fry to freshwater infectious pancreatic necrosis is largely explained by a major QTL. Heredity 105, 318-327.

Houston R.D., Haley C.S., Hamilton A., Guy D.R., Tinch A.E., Taggart J.B. \& Bishop S.C. (2008) Major quantitative trait loci affect resistance to infectious pancreatic necrosis in Atlantic salmon (Salmo salar). Genetics 178, 1109-1115.

Huang B., Tan C., Chang S.F., Munday B., Mathew J.A., Ngoh G.H. \& Kwang J. (2001) Detection of nordavirus in barramundi, Latest calcarifer (Block), using combinant coat protein-based ELISA and RT-PCR. Journal of Fish Diseases 24, 135-141

Huang Y.-C., Lin T.-S., Peng T., Chan N.-L. \& Han Y.-S. (2016) Strong inhibition of betanodavirus replication by ribavirin targeting RNA-dependent RNA polymerase. Journal of Fish Diseases 39, 619-623.

Húsgarð S., Grotmol S., Hjeltnes B.K., Rødseth O.M. \& Biering E. (2001) Immune response to a recombinant capsid protein of striped jack nervous necrosis virus (SJNNV) in turbot Scophthalmus maximus and Atlantic halibut Hippoglossus hippoglossus, and evaluation of a vaccine against SJNNV. Diseases of Aquatic Organisms, 45, 33-44.

Hwang J., Suh S.S., Park M., Oh M.J., Kim J.O., Lee S. \& Lee T.K. (2016) Detection of coat protein gene of nervous necrosis virus using loop-mediated isothermal amplification. Asian Pacific Journal of Tropical Medicine 9, 235-240.

Iwamoto T., Nakai T., Mori K., Arimoto M. \& Furusawa I. (2000) Cloning of the fish cell line SSN-1 for piscine nodaviruses. Diseases of Aquatic Organisms 43, 81-89.

Iwamoto T., Okinaka Y., Mise K., Mori K.I., Arimoto M., Okuno T. \& Nakai T. (2004) Identification of Host-Specificity Determinants in Betanodaviruses by Using Reassortants between Striped Jack Nervous Necrosis Virus and Sevenband Grouper Nervous Necrosis Virus. Journal of Virology 78, 1256-1262.

Jaramillo D., Durr S., Hick P. \& Whittington R. (2016a) Bayesian estimation of diagnostic sensitivity and specificity of a nervous necrosis virus antibody ELISA. Preventive Veterinary Medicine 123, 138-142.

Jaramillo D., Hick P., Deece K., Tweedie A., Kirkland P., Arzey E. \& Whittington R.J. (2016b) Comparison of ELISA formats for detection of antibodies specific for nervous necrosis virus (Betanodavirus) in the serum of immunized barramundi Lates calcarifer and Australian bass Macquaria novemaculeata. Aquaculture 451, 33-38.

Johansen R., Sommerset I., Tørud B., Korsnes K., Hjortaas M. J. \& Nilsen F. (2004) Characterization of nodavirus and viral encephalopathy and retinopathy in farmed turbot, Scophthalmus maximus (L.). Journal of Fish Diseases 27, 591-601. 
794

795

796

797

798

799

800

801

802

803

804

805

806

807

808

809

810

811

812

813

814

815

816

817

818

819

820

821

822

823

824

825

826

827

828

829

830

831

832

833

834

835

836

Johnson S.C., Sperker S.A. \& Leggiadro C.T. (2002) Identification and characterization of a piscine neuropathy and nodavirus from juvenile Atlantic cod from the Atlantic Coast of North America. Journal of Aquatic Animal Health 14, 124-133.

Kai Y.H., Su H.M., Tai K.T. \& Chi S.C. (2010) Vaccination of grouper broodfish (Epinephelus tukula) reduces the risk of vertical transmission by nervous necrosis virus. Vaccine 28, 996-1001.

Kai Y.H. \& Chi S.C. (2008) Efficacies of inactivated vaccines against betanodavirus in grouper larvae (Epinephelus coioides) by bath immunization. Vaccine 26, 1450-1457.

Kjøglum S., Henryon M., Aasmundstad T. \& Korsgaard I. (2008) Selective breeding can increase resistance of Atlantic salmon to furunculosis, infectious salmon anaemia and infectious pancreatic necrosis. Aquaculture Research 39, 498-505.

Kjøglum S., Larsen S., Bakke H.G. \& Grimholt U. (2006) How specific MHC class I and class II combinations affect disease resistance against infectious salmon anaemia in Atlantic salmon (Salmo salar). Fish \& Shellfish Immunology 21, 431-441.

Kuo H.C., Wang T.Y., Hsu H.H., Chen P.P., Lee S.H., Chen M.C., Tsai T.J., Wang C.K., Ku H.T., Lee G.B., Chen T.Y. (2012) Nervous necrosis virus replicates following the embryo development and dual infection with iridovirus at juvenile stage in grouper. PLoS ONE 7, e36183.

Kuo H.-P., Chung C.-L., Hung Y.-F., Lai Y.-S., Chiou P.P., Lu M.-W. \& Kong Z.-W. (2016) Comparison of the responses of different recombinant fish type I interferons against betanodavirus infection in grouper. Fish and Shellfish Immunology 49, 143-153.

Lai Y.S., Chiu H.C., Murali S., Guo I.C., Chen S.C., Fang K., Chang C.Y. (2001) Propagation of yellow grouper nervous necrosis virus (YGNNV) in a new nodavirus susceptible cell line from yellow grouper, Epinephelus awoara (Temminck \& Schlegel), brain tissue. Journal of Fish Diseases 24, 299-309.

Le Breton A., Grisez L., Sweetman J. \& Ollevier F. (1997) Viral nervous necrosis (VNN) associated with mass mortalities in cage-reared sea bass,Dicentrarchus labrax (L.). Journal of Fish Diseases 20, 145-151.

Lin C.C., Lin J.H.Y., Chen M.S. \& Yang H.L. (2007) An oral nervous necrosis virus vaccine that induces protective immunity in larvae of grouper (Epinephelus coioides). Aquaculture 268, 265-273.

Lin C.S., Lu M.W., Tang L., Liu W., Chao C.B., Lin C.J. \& Schneemann A. (2001) Characterization of virus-like particles assembled in a recombinant baculovirus system expressing the capsid protein of a fish nodavirus. Virology 290, 50-58.

Liu C., Zhang J., Yi F., Wang J., Wang X., Jiang H., Xu J. \& Hu Y. (2006a) Isolation and RNA1 nucleotide sequence determination of a new insect nodavirus from Pieris rapae larvae in Wuhan city, China. Virus research 120, 28-35.

Liu, P., Wang L., Wan Z.Y., Ye B.Q., Huang S., Wong S.M. \& Yue G.H. (2016) Mapping QTL for resistance against viral nervous necrosis disease in Asian seabass. Marine Biotechnology 18, 107-116.

Liu W., Hsu C.H., Chang C.Y., Chen H.H. \& Lin C.S. (2006b) Immune response against grouper nervous necrosis virus by vaccination of virus-like particles. Vaccine 24, 6282-6287. 
837

838

839

840

841

842

843

844

845

846

847

848

849

850

851

852

853

854

855

856

857

858

859

860

861

862

863

864

865

866

867

868

869

870

871

872

873

874

875

876

877

878

879

Lopez-Jimena B., Alonso M.D.C., Thompson K.D., Adams A., Infante C., Castro D., Borrego J.J., Garcia-Rosado E. (2011) Tissue distribution of red spotted grouper nervous necrosis virus (RGNNV) genome in experimentally infected juvenile European seabass (Dicentrarchus labrax). Veterinary microbiology 154, 86-95.

Lopez-Jimena B., Cherif N., Garcia-Rosado E., Infante C., Cano I., Castro D., Alonso M.C. (2010) A combined RT-PCR and dot-blot hybridization method reveals the coexistence of SJNNV and RGNNV betanodavirus genotypes in wild meagre (Argyrosomus regius). Journal of Applied Microbiology 109, 1361-1369.

Lu M.W., Chao Y.M., Guo T.C., Santi N., Evensen O., Kasani S.K., Hong J.R., Wu J.L. (2008) The interferon response is involved in nervous necrosis virus acute and persistent infection in zebrafish infection model. Molecular immunology 45, 1146-1152.

Massault C., Bovenhuis H., Haley C. \& Koning D.J. (2008) QTL mapping designs for aquaculture. Aquaculture 285, 23-29.

Meuwissen T., Hayes B. \& Goddard M. (2016) Genomic selection: A paradigm shift in animal breeding. Animal Frontiers 6, 6-14.

Meuwissen T.H.E., Hayes, B.J. \& Goddard, M.E., 2001. Prediction of total genetic value using Genome-Wide Dense Marker Maps. Genetics 157, 1819-1829.

Miller K.M., Winton J.R., Schulze A.D., Purcell M.K. \& Ming T.J. (2004) Major histocompatibility complex loci are associated with susceptibility of Atlantic salmon to infectious hematopoietic necrosis virus. Environmental Biology of Fishes 69, 307-316.

Moen T., Baranski M., Sonesson A.K. \& Kjøglum S. (2009) Confirmation and fine-mapping of a major QTL for resistance to infectious pancreatic necrosis in Atlantic salmon (Salmo salar): population-level associations between markers and trait. BMC Genomics 10, 368.

Moen T., Sonesson A.K., Hayes B., Lien S., Munck H. \& Meuwissen T.H.E. (2007) Mapping of a quantitative trait locus for resistance against infectious salmon anaemia in Atlantic salmon (Salmo salar): comparing survival analysis with analysis on affected/resistant data. BMC Genetics 8, 53.

Moen T., Fjalestad K.T., Munck H. \& Gomez-Raya L. (2004) A multistage testing strategy for detection of quantitative trait Loci affecting disease resistance in Atlantic salmon. Genetics 167, 851-858.

Mori K., Mangyoku T., Iwamoto T., Arimoto M., Tanaka S. \& Nakai T. (2003) Serological relationships among genotypic variants of betanodavirus. Diseases of Aquatic Organisms 57, 19-26.

Mori K., Mushiake K. \& Arimoto M. (1998) Control measures for viral nervous necrosis in striped jack. Fish Pathology, 33, 443-444.

Mori K., Nakai T., Muroga K., Arimoto M., Mushiake K. \& Furusawa I. (1992) Properties of a new virus belonging to nodaviridae found in larval striped jack (Pseudocaranx dentex) with nervous necrosis. Virology 187, 368-371.

Munday B.L., Kwang J. \& Moody N. (2002) Review article Betanodavirus infections of teleost fish: a review. Journal of Fish Diseases 25, 127-142.

Munday E.L., Langdsnb J.S., Hyaw A. \& Humphrey J.D. (1992) Mass mortality associated with vacuolating encephalopat larval and juvenile barramundi. Aqttaculture 103, 197-211. 
880 Mushiake K., Nishizawa T., Nakai T., Furusawa I. \& Muroga K. (1994) Control of VNN in 881 striped jack: Selection of spawners based on the detection of SJNNV gene by polymerase 882 chain reaction (PCR). Fish Pathology 29, 177-182.

883 Nagai T. \& Nishizawa T. (1999) Sequence of the non-structural protein gene encoded by 884 RNA1 of striped jack nervous necrosis virus. Journal of General Virology 80, 3019-3022.

885 Nishizawa T., Furuhashi M., Nagai T., Nakai T. \& Muroga K. (1997) Genomic classification 886 of fish nodaviruses by molecular phylogenetic analysis of the coat protein gene. Applied and 887 Environmental Microbiology 63, 1633-1636.

888 Nishizawa T., Muroga K. \& Arimoto M. (1996) Failure of the polymerase chain reaction 889 (PCR) method to detect striped jack nervous necrosis virus (SJNNV) in striped jack, 890 Pseudocaranx dentex, selected as spawners. Journal of Atfutttic Animal Health 8, 332-334.

891 Nishizawa T., Mori K., Furuhashi M., Nakai T., Furusawa I. \& Muroga K. (1995). 892 Comparison of the coat protein genes of five fish nodaviruses, the causative agents of viral 893 nervous necrosis in marine fish. Journal of General Virology 76, 1563-1569.

894 Nishizawa T., Nakail T. \& Muroga K. (1994) Polymerase chain reaction (PCR) amplification 895 of RNA of striped jack nervous necrosis virus (SJNNV). Diseases of Aquatic Organisms 18, 896 103-107,

897 Norris A, Foyle L. \& Ratcliff J. (2008) Heritability of mortality in response to a natural 898 pancreas disease (SPDV) challenge in Atlantic salmon, Salmo salar L., post-smolts on a West 899 of Ireland sea site. Journal of Fish Diseases 31, 913-20.

900 Nuñez-Ortiz N., Stocchi V., Toffan A., Pascoli F., Sood N., Buonocore F., Picchietti S., 901 Papeschi C., Taddei A.R., Thompson K.D. \& Scapigliati G. (2015) Quantitative 902 immunoenzymatic detection of viral encephalopathy and retinopathy virus (betanodavirus) in 903 sea bass Dicentrarchus labrax. Journal of fish diseases 39, 821-831.

904 Nylund A., Karlsbakk E., Nylund S., Isaksen T.E., Karlsen M., Korsnes K. \& Ottem K.F. 905 (2008) New clade of betanodaviruses detected in wild and farmed cod (Gadus morhua) in 906 Norway. Archives of Virology 153, 541-547.

907 Ødegård J., Baranski M., Gjerde B. \& Gjedrem T. (2011) Methodology for genetic evaluation 908 of disease resistance in aquaculture species: challenges and future prospects. Aquaculture 909 Research 42, 103-114.

910 Ødegård J., Olesen I., Dixon P., Jeney Z., Nielsen H.M., Way K. \& Gjerde B. (2010a) Genetic 911 analysis of common carp (Cyprinus carpio) strains. II: Resistance to koi herpesvirus and 912 Aeromonas hydrophila and their relationship with pond survival. Aquaculture 304, 7-13.

913 Ødegård J., Sommer A.I. \& Præbel A.K. (2010b) Heritability of resistance to viral nervous 914 necrosis in Atlantic cod (Gadus morhua L.). Aquaculture 300, 59-64.

915 Ødegård J., Olesen I., Gjerde B. \& Klemetsdal G. (2007a) Evaluation of statistical models for 916 genetic analysis of challenge-test data on ISA resistance in Atlantic salmon (Salmo salar): 917 Prediction of progeny survival. Aquaculture 266, 70-76.

918 Ødegård J., Olesen I., Gjerde B. \& Klemetsdal G. (2007b) Positive genetic correlation 919 between resistance to bacterial (furunculosis) and viral (infectious salmon anaemia) diseases 920 in farmed Atlantic salmon (Salmo salar). Aquaculture 271,173-177.

921 Okinaka Y. \& Nakai T. (2008) Comparisons among the complete genomes of four 
922 betanodavirus genotypes. Diseases of Aquatic Organisms 80, 113-21.

923 Olesen I., Hung D. \& Ødegård J. (2007) Genetic analysis of survival in challenge tests of 924 furunculosis and ISA in Atlantic salmon. Genetic parameter estimates and model 925 comparisons. Aquaculture 272, S297-S298.

926 Olveira J.G., Souto S., Dopazo C.P., Thiéry R., Barja J.L. \& Bandín I. (2009) Comparative 927

928

929

930

931

932 analysis of both genomic segments of betanodaviruses isolated from epizootic outbreaks in farmed fish species provides evidence for genetic reassortment. The Journal of general virology 90, 2940-2951.

933

934

935

936

Ozaki A., Khoo S.K., Yoshiura Y., Ototake M., Sakamoto T., Dijkstra J.M. \& Okamoto N. (2007) Identification of additional quantitative trait loci (QTL) responsible for susceptibility to infectious pancreatic necrosis virus in rainbow trout. Fish Pathology 42, 131-140.

937 Pakingking R., Bautista N.B., De Jesus-Ayson E.G. \& Reyes O. (2010) Protective immunity 938 against viral nervous necrosis (VNN) in brown-marbled grouper (Epinephelus fuscogutattus) 939 following vaccination with inactivated betanodavirus. Fish \& Shellfish Immunology 28, 525940533.

941 Palaiokostas C., Bekaert M., Taggart J.B., Gharbi K., Mcandrew B.J., Chatain B., Penman 942 D.J., Vandeputte M. (2015) A new SNP-based vision of the genetics of sex determination in 943 European sea bass (Dicentrarchus labrax). Genetics Selection Evolution 47:68.

944 Palti1 Y., Gao G., Moen T., Liu S., Kent M.P., Lien S., Miller M.R. \& Rexroad C.E. (2014) 945 The Development and Characterization of a 57K SNP Chip for Rainbow Trout. Proceedings, 946 10th World Congress of Genetics Applied to Livestock Production, August $17^{\text {th }}-22^{\text {th }}, 2014$, 947 Vancouver, BC, Canada.

948 Palti Y., Nichols K.M., Waller K.I., Parsons J.E. \& Thorgaard G.H. (2001) Association 949 between DNA polymorphisms tightly linked to MHC class II genes and IHN virus resistance 950 in backcrosses of rainbow and cutthroat trout. Aquaculture 194, 283-289.

951 Palti Y., Parsons J.E. \& Thorgaard G.H. (1999) Identification of candidate DNA markers 952 associated with IHN virus resistance in backcrosses of rainbow (Oncorhynchus mykiss) and 953 cutthroat trout (O. clarki).Aquaculture 173, 81-94.

954 Panzarin V., Fusaro A., Monne I., Cappellozza E., Patarnello P., Bovo G. \& Cattoli G. (2012) 955 Molecular epidemiology and evolutionary dynamics of betanodavirus in southern Europe. 956 Infection, Genetics and Evolution: Journal of Molecular Epidemiology and Evolutionary 957 Genetics in Infectious Diseases 12, 63-70.

958 Panzarin V., Patarnello P., Mori K., Rampazzo E., Cappellozza E., Bovo G. \& Cattoli G. 959 (2010) Development and validation of a real-time TaqMan PCR assay for the detection of 960 betanodavirus in clinical specimens. Archives of Virology 155, 1193-203.

961 Peducasse S., Castric J., Thiery R., Jeffroy J., Le Ven A. \& Laurencin F.B. (1999) 962 Comparative study of viral encephalopathy and retinopathy in juvenile sea bass Dicentrarchus 963 labrax infected in different ways. Diseases of Aquatic Organisms 36, 11-20. 
964 Qian D., Shi Z., Zhang S., Cao Z., Liu W., Li L., Xie Y., Cambournac I., Bonami J.R. (2003) 965 Extra small virus-like particles (XSV) and nodavirus associated with whitish muscle disease 966 in the giant freshwater prawn, Macrobrachium rosenbergii. Journal of Fish Diseases 26, 521967527.

968 Ransangan J. \& Manin B.O. (2012) Genome analysis of Betanodavirus from cultured marine 969 fish species in Malaysia. Veterinary microbiology 156, 16-44.

970 Ransangan J., Manin B.O., Abdullah A., Roli Z. \& Sharudin E.F. (2011) Betanodavirus 971 infection in golden pompano, Trachinotus blochii, fingerlings cultured in deep-sea cage 972 culture facility in Langkawi, Malaysia. Aquaculture 315, 327-334.

973 Rodriguez M.F., LaPatra S., Williams S., Famula T. \& May B. (2004) Genetic markers 974 associated with resistance to infectious hematopoietic necrosis in rainbow and steelhead trout 975 (Oncorhynchus mykiss) backcrosses. Aquaculture 241, 93-115.

976 Scapigliati G., Buonocore F., Randelli E., Casani D., Meloni S., Zarletti G., Tiberi M., 977 Pietretti D., Boschi I., Manchado M., Martin-Antonio B., Jimenez-Cantizano R., Bovoc G., 978 Borghesan F., Lorenzen N., Einer-Jensen K., Adamse S., Thompsone K., Alonso C., Bejar J., 979 Cano I., Borrego J.J. \& Alvarez M.C. (2010) Cellular and molecular immune responses of the 980 sea bass (Dicentrarchus labrax) experimentally infected with betanodavirus. Fish \& Shellfish 981 Immunology 28, 303-311.

982 Senapin S., Jaengsanong C., Phiwsaiya K., Prasertsri S., Laisutisan K., Chuchird N. \& Flegel 983 T.W. (2012) Infections of MrNV (Macrobrachium rosenbergii nodavirus) in cultivated 984 whiteleg shrimp Penaeus vannamei in Asia. Aquaculture 338-341, 41-46.

985 Shetty M., Maiti B., Santhosh K.S., Venugopal M.N. \& Karunasagar I. (2012) Betanodavirus 986 of marine and freshwater fish: distribution, genomic organization, diagnosis and control 987 measures. Indian Journal of Virology: An Official Organ of Indian Virological Society 23, $988 \quad 114-123$.

989 Skliris G.P., Krondiris J.V., Sideris D.C., Shinn A.P., Starkey W.G. \& Richards R.H. (2001). 990 Phylogenetic and antigenic characterization of new fish nodavirus isolates from Europe and 991 Asia. Virus Research 75, 59-67.

992 Skliris G.P. \& Richards R.H. (1999) Induction of nodavirus disease in seabass, Dicentrarchus 993 labrax, using different infection models. Virus Research 63, 85-93.

994 Sommerset I., Skern R., Biering E., Bleie H., Fiksdal I.U., Grove S. \& Nerland A.H. (2005) 995 Protection against Atlantic halibut nodavirus in turbot is induced by recombinant capsid 996 protein vaccination but not following DNA vaccination. Fish \& Shellfish Immunology 18, 1399729.

998 Sommerset I. \& Nerland A.H. (2004) Complete sequence of RNA1 and subgenomic RNA3 of 999 Atlantic halibut nodavirus (AHNV). Diseases of Aquatic Organisms 58, 117-25.

1000 Sonesson A.K. (2007) Within-family marker-assisted selection. Genetics Selection Evolution $1001 \quad 39,301-317$.

1002 Starkey W.G., Ireland J.H., Muir K.F., Shinn A.P., Richards R.H. \& Ferguson H.W. (2000) 1003 Short communication Isolation of nodavirus from Scottish farmed halibut, Hippoglossus 1004 hippoglossus (L). Journal of Fish Diseases 23, 419-422.

1005 Storset A., Strand C., Wetten M., Kjøglum S. \& Ramstad A. (2007) Response to selection for 1006 resistance against infectious pancreatic necrosis in Atlantic salmon (Salmo salar L.). 
1007

1008

1009

1010

1011

1012

1013

1014

1015

1016

1017

1018

1019

1020

1021

1022

1023

1024

1025

1026

1027

1028

1029

1030

1031

1032

1033

1034

1035

1036

1037

1038

1039

1040

1041

1042

1043

1044

1045

1046

1047

1048

Aquaculture 272, 62-68.

Su Y.C., Chiu H.W., Hung J.C. \& Hong J.R. (2014) Beta-nodavirus B2 protein induces hydrogen peroxide production, leading to Drp1-recruited mitochondrial fragmentation and cell death via mitochondrial targeting. Apoptosis 19, 1457-1470.

Sugaya T., Mori K., Nishioka T., Masuma S., Oka M., Mushiake K. \& Nakai T. (2009) Genetic heterogeneity of betanodaviruses in juvenile production trials of Pacific bluefin tuna, Thunnus orientalis (Temminck \& Schlegel). Journal of Fish Diseases 32, 815-823.

Tan C., Huang B., Chang S.F., Ngoh G.H., Munday B., Chen S.C. \& Kwang J. (2001) Determination of the complete nucleotide sequences of RNA1 and RNA2 from greasy grouper (Epinephelus tauvina) nervous necrosis virus, Singapore strain. Journal of General Virology 82, 647-653.

Tanaka S., Mori K., Arimoto M., Iwamoto T. \& Nakai T. (2001) Protective immunity of sevenband grouper, Epinephelus septemfasciatus Thunberg, against experimental viral nervous necrosis. Journal of Fish Diseases 24, 15-22.

Tanaka S., Aoki H. \& Nakai T. (1998) Pathogenicity of the nodavirus detected from diseased sevenband grouper Epinephelus septemfasciatus. Fish Pathology 33, 31-36.

Tang K.F.J., Carlos R.P., Redman R.M. \& Lightner D.V. (2007) Development of in situ hybridization and RT-PCR assay for the detection of a nodavirus (PvNV) that causes muscle necrosis in Penaeus vannamei. Disease of Aquatic Organisms 75, 183-190.

Thiéry R., Cozien J., Cabon J., Lamour F., Baud M. \& Schneemann A. (2006) Induction of a protective immune response against viral nervous necrosis in the European sea bass, Dicentrarchus labrax, by using betanodavirus virus-like particles. Journal of Virology 80, 10201-10207.

Thiéry R., Cozien J., de Boisséson C., Kerbart-Boscher S. \& Névarez L. (2004) Genomic classification of new betanodavirus isolates by phylogenetic analysis of the coat protein gene suggests a low host-fish species specificity. The Journal of General Virology 85, 3079-3087.

Thiéry R., Raymond J.C. \& Castric J. (1999) Natural outbreak of viral encephalopathy and retinopathy in juvenile sea bass, Dicentrarchus labrax: study by nested reverse transcriptasepolymerase chain reaction. Virus Research 63, 11-17.

Thiéry R., Arnauld C. \& Delsert C. (1999) Two isolates of sea bass, Dicentrarchus labrax L., nervous necrosis virus with distinct genomes. Journal of Fish Diseases 22, 201-207.

Thiéry R., Peducasse S., Castric J., Leven A., Jeffroy J. \& Laurenci F.B. (1997) Experimental transmission of viral encephalopathy and retinopathy to juvenile sea bass (Dicentrarchus Labrax). Fish Pathology 17, 118-122.

Tine M., Kuhl H., Gagnaire P.A., Louro B., Desmarais E., Martins R.S.T., Hecht J., Knaust F., Belkhir K., Klages S., Dieterich R., Stueber K., Piferrer F., Guinand B., Bierne N., Volckaert F.A.M., Bargelloni L., Power D.M., Bonhomme F., Canario A.V.M. \& Reinhardt R. (2014). European sea bass genome and its variation provide insights into adaptation to euryhalinity and speciation. Nature Communications 5:5770

Toffan A., Panzarin V., Toson M., Cecchettin K. \& Pascoli F. (2016) Water temperature affects pathogenicity of different betanodavirus genotypes in experimentally challenged Dicentrarchus labrax. Diseases of Aquatic Organisms 119, 231-238. 

(2007) Phylogeny of betanodaviruses and molecular evolution of their RNA polymerase and coat proteins. Molecular phylogenetics and evolution 43, 298-308.

Tu J., Chen W., Fu X., Lin Q., Chang O., Zhao L., Lan J., Li N. \& Lin L. (2016) Nervous Necrosis Virus (RGNNV) Infection. Int J Mol Sci 17.

Ucko M., Colorni A. \& Diamant A. (2004) Nodavirus infections in Israeli mariculture. Journal of Fish Diseases 27, 459-469.

1057 Van Regenmortel M.H.V., Fauquet C.M., Bishop D.H.L., Cartens E.B., Estes M.K., Lemon 1058 S.M., Maniloff J., Mayo M.A., McGeoch D.J., Pringle C.R. \& Wickner R.B. (2000) Virus

1059 Taxonomy: Classification and Nomenclature of Viruses. Seventh Report of the International 1060 Committee on Taxonomy of Viruses. Academic Press, San Diego.

1061 Vendramin N., Toffan A., Mancin M., Cappellozza E., Panzarin V., Bovo G., Cattoli G., 1062 Capua I. \& Terregino C (2014) Comparative pathogenicity study of ten different 1063 betanodavirus strains in experimentally infected European sea bass, Dicentrarchus labrax 1064 (L.). Journal of fish diseases 37, 371-383.

1065 Vendramin N., Patarnello P., Toffan A., Panzarin V., Cappellozza E., Tedesco P. \& Cattoli G. 1066 (2013) Viral Encephalopathy and Retinopathy in groupers (Epinephelus spp.) in southern 1067 Italy: a threat for wild endangered species. BMC Veterinary Research 9:20.

1068 Vendramin N., Padrós F., Pretto T., Cappellozza E., Panzarin V., Bovo G. \& Terregino C. 1069 (2012). Viral encephalopathy and retinopathy outbreak in restocking facilities of the 1070 endangered freshwater species, Salaria fluviatilis (Asso). Journal of Fish Diseases 35, 867107171.

1072 Verrier E.R., Dorson M., Mauger S., Torhy C., Ciobotaru C., Hervet C. \& Quillet E. (2013) 1073 Resistance to a rhabdovirus (VHSV) in rainbow trout: identification of a major QTL related to 1074 innate mechanisms. PloS One 8:55302.

1075 Vimal S., Farook M. A., Madan N., Abdul Majeed S., Nambi K.S.N., Taju G., Sundarraj N., 1076 Venu S., Subburaj R., Thirunavukkarasu A.R. \& Sahul Hameed A.S. (2016) Development, 1077 distribution and expression of a DNA vaccine against nodavirus in Asian Seabass, Lates calcarifier (Bloch, 1790). Aquaculture Research 47, 1209-1220.

1080 Wang L., Huang S.Q., Xia J.H., Liu P., Wan Z.Y. \& Yue G.H. (2015) Genome-wide discovery of gene related SNPs in Barramundi Lates calcarifer. Spinger, Conservation Genetics Resources 7, 605-608.

1082 Watanabe K., Nishizawa T. \& Yoshimiru M. (2000) Selection of brood stock candidates of 1083 barfin flounder using an ELISA system with recombinant protein of barfin flounder nervous 1084 necrosis virus. Diseases of Aquatic Organisms 41, 219-223.

1085 Watanabe K., Suzuki S., Nishizawa T., Suzuki K., Yoshimizu M. \& Ezura Y. (1998) Control 1086 strategy for viral nervous necrosis of Barfin flounder. Fish Pathology 33, 445-446.

1087 Wetten M., Aasmundstad T., Kjøglum S. \& Storset A. (2007) Genetic analysis of resistance to 1088 infectious pancreatic necrosis in Atlantic salmon (Salmo salar L.). Aquaculture 272, 111-117.

1089 Wu Y.-C., Tsai P.-Y., Chan J.-C. \& Chi S.-C. (2016) Endogenous grouper and barramundi 1090 Mx proteins facilitated the clearance of betanodavirus RNA-dependent RNA polymerase.

1091 Developmental and Comparative Immunology 59, 110-120. 
1092 Yamashita H., Mori K., Kuroda A. \& Nakai T. (2009) Neutralizing antibody levels for protection against betanodavirus infection in sevenband grouper, Epinephelus septemfasciatus (Thunberg), immunized with an inactivated virus vaccine. Journal of Fish Diseases 32, 76775 .

1096 Yáñez J.M., Houston R.D. \& Newman S. (2014a) Genetics and genomics of disease 1097 resistance in salmonid species. Frontiers in Genetics 5:415.

1098 Yáñez J.M., Naswa S., López M.E., Bassini L., Cabrejos M.E., Gilbey J., Bernatchez L., 1099 Norris A., Soto C., Eisenhart J., Simpson B., Neira R., Lhorente J.P., Schnable P., Newman 1100 S., Mileham A. \& Deeb N. (2014b) Development of a 200K SNP array for Atlantic salmon: 1101 exploiting across continents genetic variation. Proceedings, 10th World Congress of Genetics 1102 Applied to Livestock Production, August $17^{\text {th }}-22^{\text {th }}, 2014$, Vancouver, BC, Canada.

1103 Yoshikoshi K. \& Inoue K. (1990) Viral nervous necrosis in hatchery-reared larvae and 1104 juveniles of Japanese parrotfish, Oplegnathus fasciatus (Temminck \& Schlegei). Journal of 1105 Fish Diseases 13, 69-77.

1106 Yu X.Z., Meuwissen T.H.E., Baranski M. \& Sonesson A.K. (2014) Selective breeding against infectious diseases in Atlantic cod with whole genome sequence data. Proceedings, 10th World Congress of Genetics Applied to Livestock Production, August $17^{\text {th }}-22^{\text {th }}$, Vancouver, $\mathrm{BC}$, Canada.

1110 Yuasa K., Koesharyani I. \& Mahardika K. (2007) Effect of high water temperature on 1111 betanodavirus infection of fingerling Humpback grouper (Cromileptes altivelis). Fish 1112 Pathology 42, 219-221.

1113 Yuasa K., Koesharyani I., Roza D., Mori K., Katata M. \& Nakai T. (2002) Short 1114 communication immune response of humpback grouper, Cromileptes altivelis (Valenciennes), 1115 injected with the recombinant coat protein of betanodavirus. Journal of Fish Diseases 25, 53111656

1117 Zorriehzahra M.E.J., Ghasemi M., Ghiasi M., Karsidani S.H., Bovo G., Nazari A., Adel M., 1118 Arizza V. \& Dhama K. (2016) Isolation and confirmation of viral nervous necrosis (VNN) 1119 1120 disease in golden grey mullet (Liza aurata) and leaping mullet (Liza saliens) in the Iranian waters of the Caspian Sea. Veterinary Microbiology 190, 27-37. 


\begin{tabular}{ll|} 
Alphanodavirus & $\begin{array}{l}\text { Isolated in nature from insects } \\
\text { Described in suckling mice and hamsters } \\
\text { Infection resulted in paralysis and death } \\
\text { Pigs could be part of the natural host range of this genus }\end{array}$ \\
\hline
\end{tabular}

$\begin{array}{ll}\text { Betanodavirus } & \begin{array}{l}\text { Isolated in marine but also fresh water fish } \\ \text { Large variety of host species } \\ \text { Responsible of a vacuolating encephalopathy and retinopathy } \\ \text { associated with behavioral abnormalities and high mortalities }\end{array}\end{array}$

Gammanodavirus

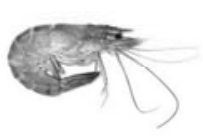

Isolated in crustaceans

Responsible of the white tail disease

Figure 1: Three genera of Nodaviridae 


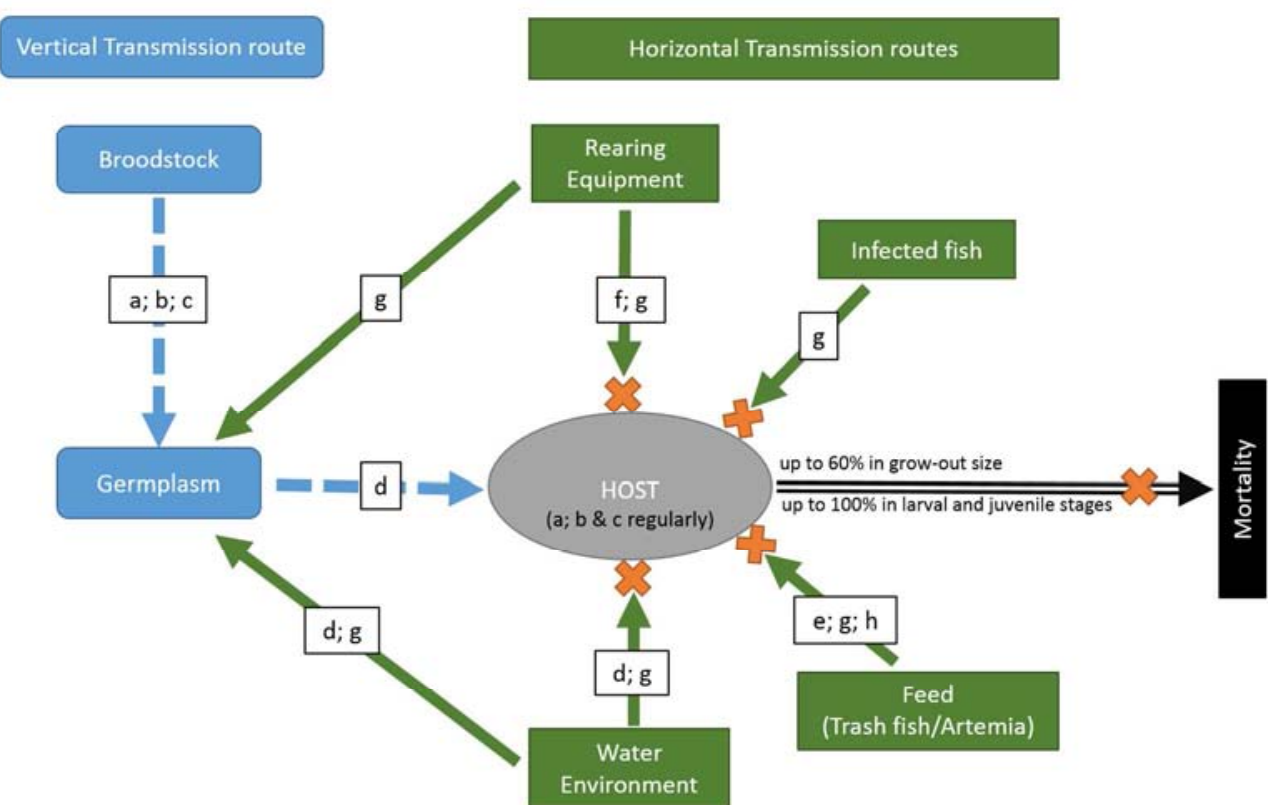

Figure 2: The different transmission routes of betanodaviruses and possible prevention modes. Blue discontinuous arrows represent vertical transmission routes; green arrows represent horizontal transmission routes; orange crosses display possible actions of genetics (by improving for fish natural barriers to infections or resistance/tolerance - see section "Selective breeding to NNV resistance: prospective procedure"); host represents either larvae/juvenile/grow-out size or broodstock; the possible prevention modes are: $a$ : vaccination; $b$ : serological diagnostic (ELISA) to screen and eliminate seropositive individuals; c: direct diagnostic (RT-qPCR) to screen and eliminate positive individuals or germplasm; d: ozone/UV/bleach water treatments; e: strict control of feed input to avoid NNV infected trash fish; f: unique equipment kit for each tank/pond/cage and adapted decontamination of equipment after use; g: Biosecurity measures during all production cycle; h: ozone treatment of artemia before feeding. 

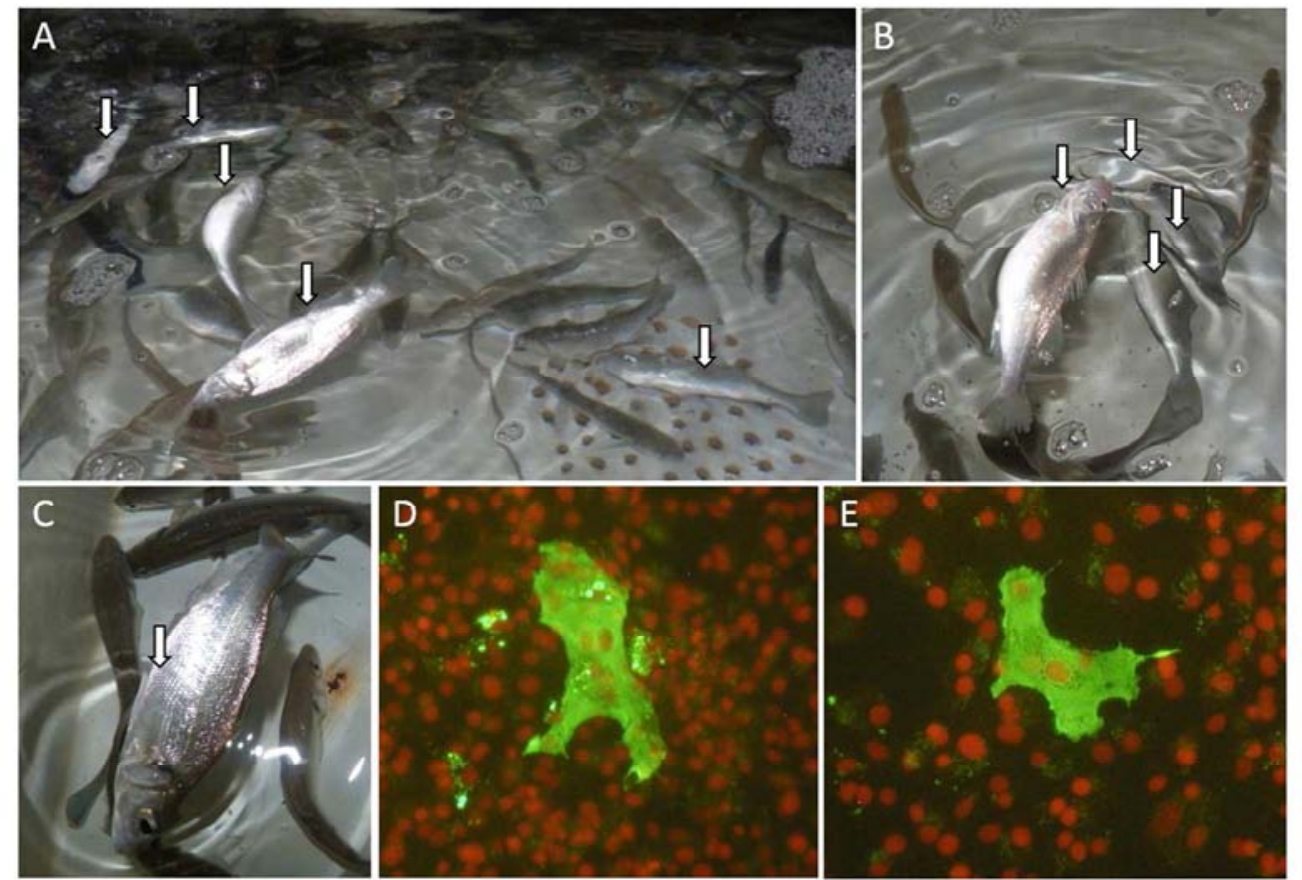

Figure 3: A, B \& C. Typical clinical signs observed during experimental NNV infection in European sea bass (arrows show impacted fish). D \& E. Positive immunofluorescence antibody test signal (in green) obtained for betanodaviruses on SSN1 cell line. Source: Anses, Ploufragan-Plouzané Laboratory, Viral diseases of fish Unit 
Table 1: Species of the genus Betanodavirus

\begin{tabular}{|c|c|c|c|c|c|}
\hline Species & GenBank accession no. & $\begin{array}{c}\text { Optimal } \\
\text { temperature } \\
\text { forreplication }\end{array}$ & Serotype & Main hosts effected & Key Ref. \\
\hline \multicolumn{6}{|c|}{ Species in the genus Betanodavivus } \\
\hline $\begin{array}{l}\text { Barfin flounder nervous necrosis } \\
\text { virus - BFNNV-BF93Hok }\end{array}$ & $\begin{array}{l}\text { RNA1 (EU826137 }=\text { NC_011063) } \\
\text { RNA2 (EU826138 }=\text { NC011064) }\end{array}$ & $15-20^{\circ} \mathrm{C}$ & $\mathrm{C}$ & $\begin{array}{l}\text { Atlantic cod (Gadus morhua) } \\
\text { Barfin flounder (Verasper moseri) } \\
\text { Atlantic halibut (Hippoglossus hippoglossus) }\end{array}$ & $\begin{array}{r}\text { Munday et al. 2002, } \\
\text { Iwamoto et al. 2000, } \\
\text { Morit et al. 2003, } \\
\text { Vendramin et al. 2013 }\end{array}$ \\
\hline $\begin{array}{l}\text { Redspotted grouper nervous } \\
\text { necrosis virus - RGNNV -SGWak97 }\end{array}$ & $\begin{array}{l}\text { RNA1 }(\text { AY324869 }=\text { NC_008040) } \\
\text { RNA2 (AY324870 }=\text { NC_008041) }\end{array}$ & $25-30^{\circ} \mathrm{C}$ & $\mathrm{C}$ & $\begin{array}{l}\text { Sevenband grouper (Epinephelus septemfasciatus) } \\
\text { Redspotted grouper (Epinephelus akaara) } \\
\text { Kelp grouper (Epinephelus moara) } \\
\text { Orange spotted grouper (Epinephelus coioides) } \\
\text { Dragon grouper (Epinephelus lanceolatus) } \\
\text { Greasy grouper (Epinephelus tauvina) } \\
\text { Humpback grouper (Cromileptes altivelis) } \\
\text { Barramundi (Lates calcarifer) } \\
\text { Japanese sea bass (Lateolabrax japonicus) } \\
\text { European sea bass (Dicentrarchus labrax) } \\
\end{array}$ & $\begin{array}{r}\text { Munday et al. 2002, } \\
\text { Iwamoto et al. 2000, } \\
\text { Mori et al. 2003, } \\
\text { Vendramin et al. 2013, } \\
\text { Vendramin et al. 2014 }\end{array}$ \\
\hline $\begin{array}{l}\text { Striped jack nervous necrosis virus } \\
\text { - SJNNV-SJ93Nag }\end{array}$ & $\begin{array}{l}\text { RNA1 (AB056571 }=\text { NC_003448) } \\
\text { RNA2 (AB056572 }=\text { NC_003449) }\end{array}$ & $20-25^{\circ} \mathrm{C}$ & A & $\begin{array}{l}\text { Japanese striped jack (Pseudocaranx dentex) } \\
\text { Gilthead sea bream (Sparus aurata) } \\
\text { Senegalese sole (Solea senegalensis) }\end{array}$ & $\begin{array}{r}\text { Nishizawa et al. 1997, } \\
\text { Iwamoto et al. 2000, } \\
\text { Mori et al. 2003, } \\
\text { Thiéry et al. 2004, } \\
\text { Vendramin et al. 2013 \& 2014 }\end{array}$ \\
\hline $\begin{array}{l}\text { Tiger puffer nervous necrosis virus } \\
\text { - TPNNV-TPKag93 }\end{array}$ & $\begin{array}{l}\text { RNA1 (EU236148 }=\text { NC_013640) } \\
\text { RNA2 (EU236149 }=\text { NC_013641) }\end{array}$ & $20^{\circ} \mathrm{C}$ & B & Tiger puffer (Takifugu rublipes) & $\begin{array}{r}\text { Iwamoto et al. 2000, } \\
\text { Mori et al. 2003, } \\
\text { Vendramin et al. 2013 }\end{array}$ \\
\hline \multicolumn{6}{|c|}{ Other genotypes which have not been approved as species } \\
\hline $\begin{array}{l}\text { Atlantic cod nervous necrosis virus } \\
\text { - ACNNV }\end{array}$ & $\begin{array}{l}\text { RNA1 (EF433472) } \\
\text { RNA2 (EF433468) }\end{array}$ & $15-20^{\circ} \mathrm{C}$ & $\mathrm{C}$ & Atlantic cod (Gadus morhua) & $\begin{array}{l}\text { Nylund et al. 2008, } \\
\text { Johnson et al. 2002 }\end{array}$ \\
\hline Atlantic halibut nodavirus - AHNV & $\begin{array}{l}\text { RNA1 (AJ401165) } \\
\text { RNA2 (AJ245641) }\end{array}$ & $15-20^{\circ} \mathrm{C}$ & $\mathrm{C}$ & Atlantic halibut (Hippoglossus hippoglossus) & $\begin{array}{r}\text { Grotmoll \& Totlandl 2000, } \\
\text { Johnson et al. 2002, } \\
\text { Sommerset \& Nerland 2004 } \\
\end{array}$ \\
\hline $\begin{array}{l}\text { Dicentrarchus labrax encephalitis } \\
\text { virus - DIEV }\end{array}$ & RNA2 (U39876) & $25-30^{\circ} \mathrm{C}$ & $\mathrm{C}$ & Sea bass (Dicentrarchus labrax) & $\begin{array}{l}\text { Dalla Valle et al. } 2001 \\
\text { Johnson et al. } 2002\end{array}$ \\
\hline $\begin{array}{l}\text { Dragon grouper nervous necrosis } \\
\text { virus - DGNNV }\end{array}$ & $\begin{array}{l}\text { RNA1 (AY721616) } \\
\text { RNA2 (AY721615) }\end{array}$ & $25-30^{\circ} \mathrm{C}$ & $\mathrm{C}$ & Dragon grouper (Epinephelus laceolatus) & $\begin{array}{r}\text { Panzarin et al. } 2012 \\
\text { Johnson et al. } 2002 \\
\end{array}$ \\
\hline $\begin{array}{l}\text { Greasy grouper nervous necrosis } \\
\text { virus - GGNNV }\end{array}$ & $\begin{array}{l}\text { RNA1 (AF319555) } \\
\text { RNA2 (AF318942) }\end{array}$ & $25-30^{\circ} \mathrm{C}$ & $\mathrm{C}$ & Greasy grouper (Epinephelustauvina) & $\begin{array}{r}\text { Tan et al. 2001, } \\
\text { Johnson et al. 2002, } \\
\text { Sommerset \& Nerland 2004 }\end{array}$ \\
\hline $\begin{array}{l}\text { Japanese flounder nervous necrosis } \\
\text { virus - JFNNV }\end{array}$ & $\begin{array}{l}\text { RNA1 (FJ748760) } \\
\text { RNA2 (D38527) } \\
\end{array}$ & $25-30^{\circ} \mathrm{C}$ & $\mathrm{C}$ & $\begin{array}{l}\text { Japanese flounder } \\
\text { (Paralichthys olivaceus) }\end{array}$ & $\begin{array}{l}\text { Panzarin et al. 2012, } \\
\text { Johnson et al. (2002) }\end{array}$ \\
\hline $\begin{array}{l}\text { Lates calcarifer encephalitis virus - } \\
\text { LcEF }\end{array}$ & RNA2 (AF175516) & $25-30^{\circ} \mathrm{C}$ & $\mathrm{C}$ & Barramundi (Lates calcarifer) & Skliris et al. 2001 \\
\hline $\begin{array}{l}\text { Malabaricus grouper nervous } \\
\text { necrosis virus - MGNNV }\end{array}$ & RNA2 (AF245003) & $25-30^{\circ} \mathrm{C}$ & $\mathrm{C}$ & Malabaricus grouper (Epinephelus malabaricus) & Johnson et al. 2002 \\
\hline $\begin{array}{l}\text { Seabass nervous necrosis virus - } \\
\text { SBNNV }\end{array}$ & RNA2 (Y08700) & $20-25^{\circ} \mathrm{C}$ & A & Sea bass (Dicentrarchus labrax) & Thiéry et al. 2004 \\
\hline $\begin{array}{l}\text { Solea senegalensis nervous necrosis } \\
\text { virus - SSNNV }\end{array}$ & $\begin{array}{l}\text { RNA1 (FJ803911) } \\
\text { RNA2 (AJ698113) }\end{array}$ & $20-25^{\circ} \mathrm{C}$ & A & Senegalese sole (Solea senegalensis) & $\begin{array}{r}\text { Panzarin et al. 2012, } \\
\text { Thiéry et al. } 2004 \\
\end{array}$ \\
\hline Turbot nodavirus - TNV & RNA2 (AJ608266) & undefined & undefined & Turbot (Scophthalmus maximus) & Johansen et al. 2004 \\
\hline $\begin{array}{l}\text { Marcrobrachium rosenbergii } \\
\text { nodavirus - MrNV }\end{array}$ & $\begin{array}{l}\text { RNA1 (AY231436) } \\
\text { RNA2 (AY231437) }\end{array}$ & $25-30^{\circ} \mathrm{C}$ & undefined & $\begin{array}{l}\text { Giant freshwater prawn (Macrobrachium } \\
\text { rosenbergii) }\end{array}$ & $\begin{array}{r}\text { Senapin et al. 2012, } \\
\text { Bonami \& Sri Widada 2011 } \\
\end{array}$ \\
\hline $\begin{array}{l}\text { Peneaus vannamei nodavirus - } \\
\text { PvNV }\end{array}$ & $\begin{array}{l}\text { RNA1 (FJ751226) } \\
\text { RNA2 (FJ751225) }\end{array}$ & $25-30^{\circ} \mathrm{C}$ & undefined & Whiteleg shrimp (Litopeneaus vannamei) & $\begin{array}{r}\text { Senapin et al. 2012, } \\
\text { Tang et al. } 2007 \\
\end{array}$ \\
\hline
\end{tabular}


Table 2: Fish species influenced by VER/VNN

\begin{tabular}{|c|c|c|c|c|c|c|}
\hline \multicolumn{5}{|c|}{ Host species } & \multirow{2}{*}{ Species } & \multirow{2}{*}{ Key ref. } \\
\hline & Oder & Family & Common name & Latin name & & \\
\hline \multicolumn{7}{|c|}{$\begin{array}{l}\text { Marine species } \\
\end{array}$} \\
\hline \multirow{36}{*}{$\begin{array}{l}\text { Farmed } \\
\text { species }\end{array}$} & Decapoda & Penaeidae & Whiteleg shrimp & Lipopenaeus vannamei & $\mathrm{PvNV}$ & Tang et al. 2007 \\
\hline & \multirow[t]{3}{*}{ Scorpaeniformes } & \multirow[t]{3}{*}{ Sebastidae } & Black rockfish & Sebastes inermis & \multirow[t]{5}{*}{ RGNNV } & \multirow[t]{5}{*}{ Gomez et al. 2004} \\
\hline & & & Oblong rockfish & S. oblongus & & \\
\hline & & & Spotbelly rockfish & S. pachycephalus & & \\
\hline & Pempheriformes & Lateolabracidae & Chinese seabass & Lateolabrax sp. & & \\
\hline & \multirow[t]{21}{*}{ Perciformes } & \multirow[t]{2}{*}{ Sparidae } & Red seabream & Pagrus major & & \\
\hline & & & Gilthead sea bream & Sparus aurata & SJNNV & Cutrín et al. 2007 \\
\hline & & Oplegnathidae & $\begin{array}{l}\text { Japanese parrotfish } \\
\text { (Barred knifejaw) }\end{array}$ & Oplegnathus fasciatus & SJNNV & $\begin{array}{l}\text { Yoshikoshi \& Inoue } 1990 \\
\text { Nishizawa et al. } 1997\end{array}$ \\
\hline & & Centropomatidae & Japanese sea bass & Lateolabrax japonicus & RGNNV & Mori et al. 2003 \\
\hline & & Sciaenidae & White sea bass & Atractoscion nobilis & RGNNV & Curtis et al. 2001 \\
\hline & & Percichthydae & European sea bass & Dicentrarchus labrax & RGNNV/SJNNV & $\begin{array}{l}\text { Breuil et al. } 1991 \\
\text { Thiéry et al. } 2004\end{array}$ \\
\hline & & Scombridae & Pacific bluefin tuna & Thunnus orientalis & RGNNV & Sugaya et al. 2009 \\
\hline & & Rachicentridae & Cobia & Rachycentron canadum & \multirow[t]{2}{*}{ RGNNV } & \multirow[t]{2}{*}{ Chi et al. 2003} \\
\hline & & \multirow{3}{*}{ Carangidae } & yellow-wax pompano & Trachinotus falcatus & & \\
\hline & & & Striped jack & Pseudocaranx dentex & SJNNV/TPNNV & $\begin{array}{l}\text { Mori et al. } 1992 \\
\text { Nishizawa et al. } 1997 \\
\end{array}$ \\
\hline & & & Golden pompano & Trachinotus blochii & RGNNV & Ransangan et al. 2011 \\
\hline & & \multirow{10}{*}{ Serranidae } & Humpback grouper & Cromileptes altivelis & RGNNV & Yuasa et al. 2007 \\
\hline & & & Dragon grouper & Epinephelus lanceolatus & RGNNV & Lin et al. 2001 \\
\hline & & & Red-spotted grouper & Epinephalus akaara & RGNNV & Nishizawa et al. 1997 \\
\hline & & & Black spotted grouper & Epinephelus fuscogutatus & RGNNV & Chi et al. 1997 \\
\hline & & & Sevenband grouper & $\begin{array}{l}\text { Epinephelus } \\
\text { septemfasciatus }\end{array}$ & SJNNV & Fukuda et al. 1996 \\
\hline & & & Greasy grouper & Epinephelus tauvina & GGNNV & $\begin{array}{l}\text { Hegde et al. } 2002 \\
\text { Tan et al. } 2001\end{array}$ \\
\hline & & & Orange-spotted grouper & Epinephelus coioides & RGNNV & Chi et al. 1999 \\
\hline & & & Brown-spotted grouper & Epinephelus malabaricus & RGNNV & Nishizawa et al. 1997 \\
\hline & & & Yellow grouper & Epinephelus awoara & RGNNV & Lai et al. 2001 \\
\hline & & & Kelp grouper & Epinephelus moara & undefined & Munday et al. 2002 \\
\hline & Tetraodontiformes & Tetraodontidae & Tiger puffer & Takifugu rubripes & TPNNV & Nishizawa et al. 1997 \\
\hline & \multirow[t]{5}{*}{ Pleuronectiformes } & Soleidae & Senegalese sole & Solea senegalensis & SJNNV & Thiéry et al. 2004 \\
\hline & & \multirow[t]{2}{*}{ Pleuronectidae } & Barfin flounder & Verasper moseri & BFNNV & Nishizawa et al. 1995 \\
\hline & & & Atlantic halibut & $\begin{array}{l}\text { Hippoglossus } \\
\text { hippoglossus }\end{array}$ & BFNNV & Grotmol et al. 1997 \\
\hline & & Paralichthyidae & Japanese flounder & Paralichthys olivaceus & SJNNV & Nishizawa et al. 1995 \\
\hline & & Scophthalmidae & Turbot & Scophthalmus maximus & TNV & Johansen et al. 2004 \\
\hline & Perciformes & Centropomatidae & $\begin{array}{l}\text { Barramundi/Asian sea } \\
\text { bass }\end{array}$ & Lates calcarifer & RGNNV & Bloch et al. 1991 \\
\hline & \multirow[t]{3}{*}{ Gadiformes } & \multirow[t]{3}{*}{ Gadidae } & Pacific cod & Gadus macrocephalus & BFNNV & Mori et al. 2003 \\
\hline & & & Atlantic cod & Gadus morhua & BFNNV & Johnson et al. 2002 \\
\hline & & & Haddock & $\begin{array}{l}\text { Melanogrammus } \\
\text { aeglefinus }\end{array}$ & BFNNV & Gagné et al. 2004 \\
\hline Wild & Perciformes & Epigonidae & $\begin{array}{l}\text { Cardinal fish } \\
\end{array}$ & Epigonus telescopus & undefined & Giacopello et al. 2013 \\
\hline species & & Serranidae & Wild dusky grouper & Epinephelus marginatus & RGNNV & Vendramin et al. 2013 \\
\hline & & & Wild golden grouper & Epinephelus costae & & \\
\hline & & Sparidae & Bogue & Boops boops (L.) & RGNNV & Ciulli et al. 2007 \\
\hline & & & Flathead grey mullet & Mugil cephalus (L.) & & \\
\hline & & Mugilidae & Golden grey mullet & Liza aurata & RGNNV & Zorriehzahra et al. 2016 \\
\hline & & & Leaping mullet & Liza saliens & & \\
\hline & & & Red mullet & $\begin{array}{l}\text { Mullus barbatus barbatus } \\
\text { (L.) }\end{array}$ & RGNNV & Ciulli et al. 2007 \\
\hline & & Gobiidae & Black goby & Gobius niger $(\mathrm{L})$. & & \\
\hline & & Carangidae & Horse mackerel & Trachurus trachurus & & \\
\hline & & & Japanese scad & $\begin{array}{lr}\text { Decapterus } & \text { maruadsi } \\
\text { (Temminck } & \& \\
\text { Schlegel) } & \\
\end{array}$ & RGNNV & Gomez et al. 2004 \\
\hline & Lepisosteiformes & Lepisosteidae & $\begin{array}{l}\text { Garpike } \\
\text { (Longnose Gar) }\end{array}$ & Lepisosteus osseus & RGNNV & Ciulli et al. 2007 \\
\hline & Pleuronectiformes & Pleuronectidae & wild winter flounder & Pleuronectes americanus & BFNNV & Gagné et al. 2004 \\
\hline & Notacanthiformes & Notacanthidae & Shortfin spiny eel & Notacanthus Bonaparte & undefined & Giacopello et al. 2013 \\
\hline & Beryciformes & Trachichthyidae & $\begin{array}{l}\text { Mediterranean } \\
\text { slimehead }\end{array}$ & $\begin{array}{l}\text { Hoplostethus } \\
\text { mediterraneus } \\
\text { mediterraneus }\end{array}$ & & \\
\hline
\end{tabular}




\begin{tabular}{|c|c|c|c|c|c|c|}
\hline & \multirow[t]{3}{*}{ Gadiformes } & Macrouridae & Glasshead grenadier & $\begin{array}{l}\text { Hymenocephalus italicus } \\
\text { (Giglioli) }\end{array}$ & & \\
\hline & & Gadidae & Whiting & Merlangi merlangus $(\mathrm{L})$. & \multirow[t]{4}{*}{ RGNNV } & \multirow[t]{4}{*}{ Ciulli et al. 2007} \\
\hline & & Merlucciidae & European hake & $\begin{array}{l}\text { Merluccius merluc- cius } \\
\text { (L.) }\end{array}$ & & \\
\hline & Clupeiformes & Clupeidae & European pilchard & $\begin{array}{ll}\text { Sardina } & \text { pilchardus } \\
\text { (Walbaum) } & \end{array}$ & & \\
\hline & \multirow[t]{2}{*}{ Scorpaeniformes } & Triglidae & Gurnard & $\begin{array}{l}\text { Chelidonichthys lucerna } \\
\text { (L.) }\end{array}$ & & \\
\hline & & Sebastidae & Marbled rockfish & $\begin{array}{l}\text { Sebastiscus marmoratus } \\
\text { (Cuvier) }\end{array}$ & \multirow[t]{3}{*}{ RGNNV } & \multirow[t]{3}{*}{ Gomez et al. 2004} \\
\hline & \multirow[t]{2}{*}{ Tetraodontiformes } & \multirow[t]{2}{*}{ Monacantidae } & Threadsail filefish & $\begin{array}{l}\text { Stephanolepis cirrhifer } \\
\text { (Temminck \& Schlegel) }\end{array}$ & & \\
\hline & & & Black scraper & $\begin{array}{l}\text { Thamnaconus modestus } \\
\text { (Gunther) }\end{array}$ & & \\
\hline & \multirow[t]{2}{*}{ Decapoda } & Portunidae & Charybdid crab & Charybdis bimaculata & \multirow[t]{3}{*}{ RGNNV } & \multirow[t]{3}{*}{ Gomez et al. 2008} \\
\hline & & Pandalidae & $\begin{array}{l}\text { Southern humpback } \\
\text { shrimp }\end{array}$ & Pandalus hypsinotus & & \\
\hline & Mytiloida & Mytilidae & Mediterranean mussel & Mytilus galloprovincialis & & \\
\hline \multicolumn{7}{|c|}{ Freshwater species } \\
\hline \multirow{9}{*}{$\begin{array}{l}\text { Farmed } \\
\text { species }\end{array}$} & Acipenseriformes & Acipenseridae & Sturgeon & Acipenser gueldenstaedi & SJNNV & Athanassopoulou et al. 2004 \\
\hline & Anguilliformes & Anguillidae & European eels & Anguilla anguilla & \multirow[t]{2}{*}{ RGNNV } & \multirow[t]{2}{*}{ Chi et al. (2003) } \\
\hline & \multirow[t]{2}{*}{ Siluriformes } & \multirow[t]{2}{*}{ Siluridae } & Chinese catfish & Parasilurus asotus & & \\
\hline & & & Australian catfish & Tandanus tandanus & undefined & \multirow[t]{2}{*}{ Shetty et al. 2012} \\
\hline & \multirow[t]{4}{*}{ Perciformes } & Eleotridae & Sleepy cod & Oxyeleotris lineolatus & undefined & \\
\hline & & Centrarchidae & Largemouth black bass & $\begin{array}{ll}\begin{array}{l}\text { Micropterus } \\
\text { (Lacepede) }\end{array} & \text { salmoides } \\
\end{array}$ & \multirow[t]{2}{*}{ RGNNV } & \multirow[t]{2}{*}{ Bovo et al. 2011} \\
\hline & & Percidae & Pike-perch & Sander lucioperca & & \\
\hline & & Cichlidae & Tilapia & Oreochromis niloticus & RGNNV & Bigarré et al. 2009 \\
\hline & Decapoda & Palaemonidae & $\begin{array}{ll}\text { Giant } & \text { freshwater } \\
\text { prawn } & \\
\end{array}$ & $\begin{array}{l}\text { Macrobrachium } \\
\text { rosenbergii }\end{array}$ & $\mathrm{MrNV}$ & Bonami \& Widada 2011 \\
\hline \multirow{5}{*}{$\begin{array}{l}\text { Orname } \\
\text { ntal/mo } \\
\text { del fish } \\
\text { species }\end{array}$} & Cyprinodontiformes & Poeciliidae & Guppy & Poecilia reticulata & RGNNV & Hegde et al. 2003 \\
\hline & \multirow[t]{2}{*}{ Cypriniformes } & \multirow[t]{2}{*}{ Cyprinidae } & Zebrafish & Danio rerio & RGNNV & Lu et al. 2008 \\
\hline & & & Goldfish & Carassius auratus & RGNNV & Binesh 2013 \\
\hline & Perciformes & Blenniidae & Freshwater blenny & Salaria fluviatili & RGNNV & Vendramin et al. 2012 \\
\hline & Beloniformes & Adrianichthyidae & Medaka & Oryzias latipes & RGNNV & Furusawa et al. 2006 \\
\hline
\end{tabular}


Table 3: Primers/probes sets used for betanodavirus detection by RT-PCR

\begin{tabular}{|c|c|c|c|c|c|}
\hline Primer/Probe & Target & GenBank accession number ${ }^{\S}$ & Sequence 5' - 3' & Position & Key Ref. \\
\hline $\begin{array}{l}\text { VNNV1 } \\
\text { VNNV2 } \\
\text { VNNV3 } \\
\text { VNNV4 }\end{array}$ & RNA2 & AB056572 & $\begin{array}{l}\text { ACACTGGAGTTTGAAATTCA } \\
\text { GTCTTGTTGAAGTTGTCCCA } \\
\text { ATTGTGCCCCGCAAACAC } \\
\text { GACACGTTGACCACATCAGT }\end{array}$ & $\begin{array}{l}343-362 \\
953-934 \\
366-383 \\
620-601\end{array}$ & Dalla Valle et al. 2000 \\
\hline $\begin{array}{l}\text { AH95-F1 } \\
\text { AH95-R1 }\end{array}$ & RNA2 & AJ245641 & $\begin{array}{l}\text { AGTGCTGTGTCGCTGGAGTG } \\
\text { CGCCCTGTGTGAATGTTTTG }\end{array}$ & $\begin{array}{l}577-596 \\
917-898\end{array}$ & Grotmoll \& Totlandl 2000 \\
\hline $\begin{array}{l}\text { F2 } \\
\text { R3 }\end{array}$ & RNA2 & AB056572 & $\begin{array}{l}\text { CGTGTCAGTCATGTGTCGCT } \\
\text { CGAGTCAACACGGGTGAAGA }\end{array}$ & $\begin{array}{c}592-611 \\
1017-998\end{array}$ & Nishizawa et al. 1994 \\
\hline $\begin{array}{l}F^{\prime} 2 \\
\text { R'3 }\end{array}$ & RNA2 & Y08700 & $\begin{array}{l}\text { GTTCCCTGTACAACGATTCC } \\
\text { GGATTTGACGGGGCTGCTCA }\end{array}$ & $\begin{array}{l}677-693 \\
970-951\end{array}$ & Thiéry et al. 1999 \\
\hline $\begin{array}{l}\text { Q-CP-1 } \\
\text { Q-CP-2 }\end{array}$ & RNA2 & D38636 & $\begin{array}{l}\text { CAACTGACAACGATCACACCTTC } \\
\text { CAATCGAACACTCCAGCGACA }\end{array}$ & $\begin{array}{l}234-256 \\
463-443\end{array}$ & Dalla Valle et al. 2005 \\
\hline $\begin{array}{l}\text { P1 } \\
\text { P2 } \\
\text { Probe }\end{array}$ & RNA2 & AJ245641 & $\begin{array}{l}\text { GGTATGTCGAGAATCGCCC } \\
\text { TAACCACCGCCCGTGTT } \\
\text { TTATCCCAGCTGGCACCGGC* }\end{array}$ & $\begin{array}{l}141-159 \\
351-335 \\
183-202\end{array}$ & Grove et al. 2006 \\
\hline $\begin{array}{l}\text { qR2TF } \\
\text { qR2TR } \\
\text { R2probe2 }\end{array}$ & RNA2 & LcNNV09_07 ${ }^{\ddagger}$ & $\begin{array}{l}\text { CTTCCTGCCTGATCCAACTG } \\
\text { GTTCTGCTTTCCCACCATTTG } \\
\text { CAACGACTGCACCACGAGTTG* }\end{array}$ & $\begin{array}{l}378-397 \\
470-451 \\
448-428\end{array}$ & Hick \& Whittington 2010 \\
\hline $\begin{array}{l}\text { RNA2 FOR } \\
\text { RNA2 REV } \\
\text { probe }\end{array}$ & RNA2 & DQ864760 & $\begin{array}{c}\text { CAACTGACARCGAHCACAC } \\
\text { CCCACCAYTTGGCVAC } \\
\text { TYCARGCRACTCGTGGTGCVG* }\end{array}$ & $\begin{array}{l}392-410 \\
460-445 \\
422-442 \\
\end{array}$ & Panzarin et al. 2010 \\
\hline $\begin{array}{l}\text { Nod1f } \\
\text { Nod1r }\end{array}$ & RNA2 & $\begin{array}{c}\text { EF617335; AY744705; AF 175511; } \\
\text { AB056572; AJ608266; D38637; D38635 }\end{array}$ & $\begin{array}{c}\text { TTCCAGCGATACGCTGTTGA } \\
\text { CACCGCCCGTGTTTGC } \\
\text { AAATTCAGCCAATGTGC* }\end{array}$ & $\begin{array}{l}322-341^{\mathrm{d}} \\
376-391^{\mathrm{d}} \\
356-372^{\mathrm{d}}\end{array}$ & Hodneland et al. 2011 \\
\hline $\begin{array}{l}\text { Nod2f } \\
\text { Nod2r }\end{array}$ & RNA2 & $\begin{array}{c}\text { EF617335; AY744705; AF 175511; } \\
\text { AB056572; AJ608266; D38637; D38635 }\end{array}$ & $\begin{array}{c}\text { CTGGGACACGCTGCTAGAATC } \\
\text { TGGTCGTTGTCAGTTGGATCA } \\
\text { AAATTCAGCCAATGTGC* }\end{array}$ & $\begin{array}{l}301-321^{\mathrm{d}} \\
414-434^{\mathrm{d}} \\
356-372^{\mathrm{d}}\end{array}$ & Hodneland et al. 2011 \\
\hline $\begin{array}{l}\text { RG-RNA2-F2: } \\
\text { RG- RNA2-R2: }\end{array}$ & RNA2 & D38636 & $\begin{array}{l}\text { CGTCCGCTGTCCATTGACTA } \\
\text { CTGCAGGTGTGCCAGCATT }\end{array}$ & $\begin{array}{l}624-643 \\
723-705\end{array}$ & Lopez-Jimena et al. 2011 \\
\hline $\begin{array}{l}\text { oPVP111 } \\
\text { oPVP88 }\end{array}$ & RNA2 & $\begin{array}{c}\text { AF245003; AF245004; AF281657; } \\
\text { AF499774; AJ245641 ; AJ608266 ; D30814; } \\
\text { U39876 ; EF433468; AY549548; EU236149 }\end{array}$ & $\begin{array}{l}\text { TCCTGCCTGAYCCAACTGAC } \\
\text { TGGTCATCMACGATACGCAC }\end{array}$ & $\begin{array}{c}381-400^{\mathrm{p}} \\
1058-1039^{\mathrm{p}}\end{array}$ & Bigarré et al. 2010 \\
\hline $\begin{array}{l}\text { Q-RdRP-1 } \\
\text { Q-RdRP-2 }\end{array}$ & RNA1 & $\mathrm{D} 38636$ & $\begin{array}{l}\text { GTGTCCGGAGAGGTTAAGGATG } \\
\text { CTTGAATTGATCAACGGTGAACA }\end{array}$ & $\begin{array}{l}589-610 \\
861-839\end{array}$ & Dalla Valle et al. 2005 \\
\hline $\begin{array}{l}\text { RG-RNA1-F: } \\
\text { RG-RNA1-R: }\end{array}$ & RNA1 & AY369136 & $\begin{array}{c}\text { GGCTCAGATCTGGTAATGTTTCAA } \\
\text { CAAAGCCAAGGGAAGAAGCA }\end{array}$ & $\begin{array}{l}2144-2167 \\
2206-2187\end{array}$ & Lopez-Jimena et al. 2011 \\
\hline $\begin{array}{l}\text { oPVP154 } \\
\text { oPVP155 } \\
\text { Taqman-Probe }\end{array}$ & RNA1 & $\begin{array}{l}\text { AJ401165; EF617335; EU826137; } \\
\text { AB025018; AB056571; AF319555; } \\
\text { GQ402010; GQ402012; AY690597 }\end{array}$ & $\begin{array}{l}\text { TCCAAGCCGGTCCTAGTCAA } \\
\text { CACGAACGTKCGCATCTCGT } \\
\text { CGATCGATCAGCACCTSGTC* }\end{array}$ & $\begin{array}{l}2717-2736^{*} \\
2884-2865^{*}\end{array}$ & Baud et al. 2015 \\
\hline
\end{tabular}

$\S_{\text {sequences from wich the primers or probes have been designed; *label position on probes; }{ }^{\ddagger} \text { the primers and probe design was }}$ achieved on an isolate obtained from a infected barramundi sampled but not reported in GenBank (Hick \& Whittington, 2010); ${ }^{\mathrm{d}}$ the position of the primers and probe are based on SJNNV genome (AB056572); ${ }^{\mathrm{P}}$ the position of the primers and probe are based on BFNNV genome (AY549548); ${ }^{¥}$ the position of the primers and probe are based on BFNNV genome (AJ401165). 
Table 4: The different types of NNV vaccine tested in fish

\begin{tabular}{|c|c|c|c|c|}
\hline Type of Vaccinations & Species & Method & Results/RPS & Key Ref. \\
\hline \multicolumn{5}{|l|}{ Inactivated vaccines } \\
\hline $\begin{array}{l}\text { - BEI-inactivated HGNNV vaccine } \\
\text { - Formalin-inactivated vaccines }\end{array}$ & $\begin{array}{l}\text { Orange-spotted grouper Epinephelus coioides } \\
\text { (early larval stage-40 dph with average body weight (BW) of } 0.2 \\
\mathrm{~g} \text { and TBL of } 2.4 \mathrm{~cm} \text { ) }\end{array}$ & immersion & $\begin{array}{l}-\mathrm{RPS}=79 \% \text { (BEI-inactivated NNV vaccines) } \\
-39 \% \text { (Formalin-inactivated NNV vac-cines) }\end{array}$ & Kai \& Chi 2008 \\
\hline Formalin-inactivated vaccine (RGNNV) & $\begin{array}{l}\text { Sevenband grouper Epinephelus septemfasciatus (juvenile-25.4 } \\
\mathrm{g} \text { ) }\end{array}$ & injection & $\begin{array}{c}60 \% \text { in fish groups immunized with } 10^{7.5} \mathrm{TCID}_{50} \text { per fish or } \\
\text { higher doses. }\end{array}$ & Yamashita et al. 2009 \\
\hline BEI-inactivated HGNNV vaccine & $\begin{array}{l}\text { Adult Orange-spotted grouper Epinephelus coioides (mean body } \\
\text { weight of } 1.35 \mathrm{~kg} \text { ) }\end{array}$ & injection & High efficiency & Kai et al. 2010 \\
\hline Formalin-inactivated vaccine (RGNNV type) & Brown-marbled grouper Epinephelus fuscogutattus (5g) & injection & $86-100 \%$ & Pakingking et al. 2010 \\
\hline \multicolumn{5}{|l|}{ Recombinant vaccines } \\
\hline $\begin{array}{l}\text { Recombinant capsid protein vaccine (Artemia- } \\
\text { encapsulated recombinant } E \text {. coli expressing the } \\
\text { NNV capsid protein gene) }\end{array}$ & Orange-spotted grouper Epinephelus coioides (Larvae-35dph) & oral & $64.5 \%$. & Lin et al. 2007 \\
\hline $\begin{array}{l}\text { Recombinant capsid protein (Vibrio anguillarum- } \\
\text { based oral vaccine) }\end{array}$ & Orange-spotted grouper Epinephelus coioides (fry) & oral & $78.3 \%$ & Chen et al. 2011 \\
\hline Recombinant capsid protein (rT2 vaccine) & $\begin{array}{l}\text { Turbot Scophthalmus maximus (weighing from } 1 \text { to } 3 \mathrm{~g} \text { (mean } \\
1.8 \mathrm{~g} \text { )) }\end{array}$ & injection & $82 \%$ & Húsgarð et al. 2001 \\
\hline $\begin{array}{l}\text { Recombinant capsid protein vaccine (recAHNV-C) } \\
\& \text { vaccine plasmid (called pAHNV-C) }\end{array}$ & Turbot Scophthalmus maximus (Juvenile-mean weight $2.2 \mathrm{~g}$ ) & injection & $\begin{array}{l}-50 \% \% \text { in fish groups immunized with recAHNV-C }(10 \mathrm{mg})+ \\
\text { pAHNV-C }(5 \mathrm{mg}) \\
-57 \% \text { in fish groups immunized with recAHNV-C }(10 \mathrm{mg})\end{array}$ & Sommerset et al. 2005 \\
\hline Recombinant protein vaccine-E.coli BL21 (DE3) & Sevenband grouper Epinephelus septemfasciatus (28g) & injection & $88 \%$ in fish groups immunized with $10^{3.4} \mathrm{TCID}_{50}$ per fish & Tanaka et al. 2001 \\
\hline \multicolumn{5}{|l|}{ VLPs vaccines } \\
\hline Virus-like particles (VLPs) of GNNV & $\begin{array}{l}\text { - Dragon grouper Epinephelus lanceolatus }(20 \mathrm{~g}) \\
\text { - Malabar grouper Epinephelus malabaricus }(20 \mathrm{~g})\end{array}$ & injection & Significant efficiency & Liu et al. 2006b \\
\hline $\begin{array}{l}\text { Virus-like particles (VLPs) } \\
\text { - MGNNV VLPs (trial 1) } \\
\text { - SB2 VLPs (trial 2) }\end{array}$ & $\begin{array}{l}\text { European sea bass Dicentrarchus larbrax } \\
-66 \mathrm{~g} \\
-22 \mathrm{~g}\end{array}$ & injection & $\begin{array}{l}-71.7-89.4 \% \\
-27.4-88.9 \%\end{array}$ & Thiéry et al. 2006 \\
\hline \multicolumn{5}{|l|}{ DNA vaccines } \\
\hline pFNCPE42-DNA vaccine & Asian sea bass Lates calcarifier (juvenile stage) & injection & $77.33 \%$ & Vimal et al. 2016 \\
\hline
\end{tabular}


Table 5: Recent heritability estimates of resistance to viral diseases in farmed fish species

\begin{tabular}{|c|c|c|c|c|c|}
\hline \multirow{2}{*}{ Pathogen } & \multirow{2}{*}{ Species (host) } & \multicolumn{2}{|c|}{ Heritability: $\mathbf{h}^{2}( \pm$ S.E. $)$} & \multirow[b]{2}{*}{ Notes } & \multirow[t]{2}{*}{ Key ref. } \\
\hline & & Binary traits & Time until death & & \\
\hline VNNV & $\begin{array}{l}\text { Atlantic cod } \\
\text { (Gadus morhua) }\end{array}$ & $\begin{array}{l}\mathrm{h}^{2}=0.75( \pm 0.11) \\
\mathrm{h}^{2}=0.68( \pm 0.14) \\
\mathrm{h}^{2}=0.91\end{array}$ & & $\begin{array}{l}\text { Threshold model (on the underlying scale) } \\
\text { Threshold model (on the underlying scale) } \\
\text { CURE model }\end{array}$ & $\begin{array}{l}\text { Ødegård et al. } 2010^{\mathrm{b}} \\
\text { Bangera et al. } 2011 \\
\text { Bangera et al. } 2013\end{array}$ \\
\hline VHSV & $\begin{array}{l}\text { Rainbow trout } \\
\text { (Oncorhynchus mykiss) }\end{array}$ & $\begin{array}{l}\mathrm{h}^{2}=0.63( \pm 0.26) \\
\mathrm{h}^{2}=0.57\end{array}$ & $\begin{array}{l}\mathrm{h}^{2}=0.13 \\
\mathrm{~h}^{2}=0.11( \pm 0.10)\end{array}$ & $\begin{array}{l}\text { Linear model (angular transformation) } \\
\text { On the logarithmic-time scale } \\
\text { Survival, liability scale }\end{array}$ & $\begin{array}{l}\text { Dorson et al. } 1995 \\
\text { Henryon et al. } 2002 \\
\text { Henryon et al. } 2005\end{array}$ \\
\hline ISAV & $\begin{array}{l}\text { Atlantic salmon } \\
\text { (Salmo salar) }\end{array}$ & $\begin{array}{l}\mathrm{h}^{2}=0.24( \pm 0.03) \\
\mathrm{h}^{2}=0.318( \pm 0.022) \\
\mathrm{h}^{2}=0.319( \pm 0.022) \\
\mathrm{h}^{2}=0.37 \\
\mathrm{~h}^{2}=0.40( \pm 0.04)\end{array}$ & $\begin{array}{l}\mathrm{h}^{2}=0.13( \pm 0.03)(\text { O.S. }) \\
\mathrm{h}^{2}=0.19 \text { (U.S.) }\end{array}$ & $\begin{array}{l}\text { Linear model (Observable scale)/ } \\
\text { On the underlying liability scale } \\
\text { Threshold model using cross-sectional data } \\
\text { Threshold model (on the underlying scale) } \\
\text { Threshold model (on the underlying scale) } \\
\text { On the underlying liability scale } \\
\text { On the underlying liability scale }\end{array}$ & $\begin{array}{l}\text { Gjøen et al. } 1997 \\
\text { Olesen et al. } 2007 \\
\text { Ødegård et al. } 2007^{\mathrm{a}} \\
\text { Ødegård et al. } 2007^{\mathrm{b}} \\
\text { Kjøglum et al. } 2008 \\
\text { Gjerde et al. } 2009 \\
\end{array}$ \\
\hline IPNV & $\begin{array}{l}\text { Atlantic salmon } \\
\text { (Salmo salar) }\end{array}$ & $\begin{array}{l}\mathrm{h}^{2}=0.43 \\
\mathrm{~h}^{2}=0.31 \\
\mathrm{~h}^{2}=0.55 \\
\mathrm{~h}^{2}=0.38( \pm 0.017)\end{array}$ & $\mathrm{h}^{2}=0.16$ & $\begin{array}{l}\text { transformed to the liability scale/Observed } \\
\text { Linear model (Observable scale) } \\
\text { On the underlying liability scale } \\
\text { On the underlying liability scale }\end{array}$ & $\begin{array}{l}\text { Guy et al. } 2006 \\
\text { Wetten et al. } 2007 \\
\text { Kjøglum et al. } 2008 \\
\text { Guy et al. } 2009\end{array}$ \\
\hline SPDV & $\begin{array}{l}\text { Atlantic salmon } \\
\text { (Salmo salar) }\end{array}$ & & $\mathrm{h}^{2}=0.21( \pm 0.005)$ & $\begin{array}{l}\text { transformed to the liability scale/ Linear } \\
\text { model (Observable scale)/ }\end{array}$ & Norris et al. 2008 \\
\hline KHV & $\begin{array}{l}\text { Common carp } \\
\text { (Cyprinus carpio) }\end{array}$ & $\mathrm{h}^{2}=0.79( \pm 0.14)$ & & On the underlying liability scale & Ødegård et al. $2010^{\mathrm{a}}$ \\
\hline
\end{tabular}

